\title{
ARMENIAN AMULETS FROM THE COLLECTION OF ARMENIAN ORTHODOX DIOCESE IN BAGHDAD
}

\section{Lusine Sargsyan}

Researcher at the Matenadaran Research Institute of Ancient Manuscripts, and a Visiting Lecturer at Yerevan State University

sargsianlusin@gmail.com

\section{Davit Ghazaryan}

Senior Researcher, Curator of the Manuscript Depository of the Matenadaran Research Institute of Ancient Manuscripts, and a Lecturer at the Department of Armenian Art History and Theory at Yerevan State University davit.ghazaryan@matenadaran.am

\begin{abstract}
This study is dedicated to the Armenian manuscript and printed Amulets ${ }^{1}$ of the Armenian Diocese of Baghdad (DAOB). In this collection of early printings, there are two printed Amulets in scroll (Pr. n. 14, second half of the 19th century and Pr. n. 15, A.D. 1716). The third Amulet is a manuscript written in 1736 in the city of Erzrum (Karin) for a certain Ohan (Ms. n. 13). The scanned copies of these amulets are currently available through the website of Hill Museum and Manuscript Library (HMML). ${ }^{2}$ Since this paper is the first study of these amulets, it presents them in terms of codicology and bibliographical study and discusses their decoration. The study of some iconographic details will help to reveal the practice of using
\end{abstract}


amulets and their meaning, considering them as a representation of Armenian "folklore-art", since scribes and miniaturists were partly free to choose texts and decorate them, even they were mostly works of the priesthood. ${ }^{3}$

It should be noted that as artifacts of the same genre, having a purpose of protection of their owners using incantations and prayers, very often the content and decoration of these three Amulets have similarities. From this point of view, Ms. n. 13 (A.D. 1736) and Pr. n. 15 (A.D. 1716) are more relevant to each other both in content and, accordingly, in decoration. A selection of prayers and illustrations to them show almost the same structure, and for the printed Amulet, we can certainly argue that such structure was typical (but not limited) for the printed Amulets in the Armenian tradition from the 18th to 19 th centuries. Despite some similarities with two previous Amulets, the Pr. n. 14 (19th century) represent another structure of content and its decoration. It is enriched with prayers and illustrations which does not exist in mentioned above two examples of the 18th century. E.g. engravings depicting the life of Christ (Annunciation, Birth of Jesus Christ, Baptism, Resurrection, etc.), or portraits of the evangelists, accompanied by the passages from their Gospels. Our research shows that the publishers of this Amulet had an eighteenth-century prototype and took an innovative approach using Western art engravings.

Key words: amulet, miniature, engraving, demon, al, saint, beard pulling, goat, early printing, protection, folklore.

\section{INTRODUCTION}

Since not all specialists in studies on charms, charmers and charming are familiar with Armenian amulets, we find useful an introductory note on handwritten amulets' practice and role, as well as on the largest collections where these amulets currently are kept. Previously, the authors of this article had the opportunity to publish on this topic (see in Ghazaryan, Sargsyan 2016: 13-15).

<uujhlitip ("Hmayilner", 'Amulets') - a collection of spells - among the ancient Armenian manuscripts differ by their shape (a scroll), and miniatures. They are objects prepared with 'magic' prayers, aimed to preserve their holders from various misfortunes (Mescherskaya 1981: 96). The word <uuhl ("Hmail”) originates from Pahlavi (Old Persian) humav = 'blessing' (Malxaseanc 1944: 113, Ačaŕyan 1977: 103). The scribes called the collection of spells <uuhl

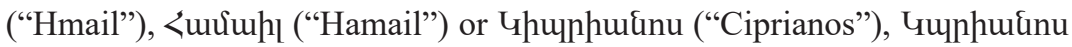
("Cprianos"), Ghupuqhp ("Niatagir"). ${ }^{4}$ As a rule, by the name "Cyprianos" are called the amulets which include the story of the bishop Cyprian (3rd -4 th 
centuries). The story tells that Cyprian was a mage who commanded many demons and devils. Later he converted to Christianity (Ghazaryan 2014: 243-264).

The roll is the oldest form for magic miscellanies and its roots go back to old magic experience. People used to believe that rolled prayers or maledictions cannot be touched by outside spiteful influence and, thus, acquire great power (Mescherskaya 1981: 96). This is the reason why the oldest form of Armenian amulets or magical miscellanies is a roll or ribbon. In the Armenian tradition, amulets are of different sizes: the small ones are less than a metre, and the longest one is $2776.7 \mathrm{~cm}$ in length (National Library of France, BnF, Arménien 348). The earliest examples of Armenian amulets in scroll which are known to us belong to the 15 th century. The dated oldest one is from 1428, and is kept in Matenadaran (Yerevan, Armenian Amulet 116, see in Ghazaryan 2012: 147-61).

The biggest collection of amulets in scroll is also in Matenadaran (Armenia; 560). There are also amulets in the collections of Holy Saviour Cathedral in New Julfa (Iran; 57, see Minasean 1983-1984; Ghazaryan 2019: 460-67), in the Mother See of Holy Etchmiadzin (Armenia; 46, see in C'uc'ak Mayr Atoŕ Surb Eĵmiacni nor stac'vac jeréagreri: 1952: 59-60; 1961: 59; 1962: 63; 1963 : 61-62; 1970: 58-59; 1971: 61-62; 1971: 46; 1975: 60-63), in the libraries of Mxitarists' Congregations in Venice (44, see Fejdit 1986; Tēr-Vardanean 2013: 62-98) and in Vienna (11, see Voskean 1963: 383-5, 879-80; Sēkulean 1983: 378-9, 1000), in the History Museum of Armenia in Yerevan (13), in the British Library in London (13, see Nersessian 2012, v. II, 1077-1110, v. I, pl. XXVIII), and in other state and private collections.

The collection of Armenian amulets in Iraq is smaller than the collections mentioned above, however it is important evidence for the existence of Armenians in Iraq. So we consider a historical overview necessary. The presence of Armenians in Iraq has been known since ancient times. Armenians settled mainly in Baghdad, Basra, Mosul and other cities. In the 14th century, an Armenian community and Bishopric were already established in Baghdad under the rule of the Tatars (Alpōyačean 2003: 29). Later, in 1623 with the capture of Baghdad by the Persian Shah Abbas the First, and then in 1638 by the Ottoman Sultan Murat IV, the number of Armenians in the city increased significantly (Alpōyačean 2003: 35, 69). Groups of Armenian immigrants who survived the Armenian Genocide in the Ottoman Empire in 1915 found refuge in Iraq, and in a number of other Middle Eastern countries. The Diocese of the 
Armenian Apostolic Church in Iraq was formed in 1944, and the seat of the Bishopric is the Saint Gregory the Illuminator Church in Baghdad (Sargsyan, Petrosyan 2003: 270). During migration, and sometimes forced resettlements, the Armenians carried with them manuscripts and books of various contents, in particular, amulets for their own protection, and the Iraqi-Armenians are no exception. This may be one of the reasons for the existence of Armenian manuscripts and books in Iraq.

Studies on Armenian manuscripts and early printed books stored in Iraq are still scarce. Only the descriptions of a few manuscripts are known to us from the Saint Trinity Church of Baghdad (Kiwrtean 1932: 347-8) ${ }^{5}$ and from the Saint Astvatsatsin (Mother of God) Church of Basra (Samuēlean 1905: 326-9). ${ }^{6}$ In this regard, the study of the manuscript and printed amulets of the Armenian Diocese of Baghdad is very important, since it makes these artifacts known in the scientific environment and represents the first attempt of their study.

\section{THE MANUSCRIPT AMULETS}

The Amulet (Appendix 1) is illustrated with scenes and figures from the Old and New Testaments, as well as with images of saints protecting from evil forces, and of an Armenian saint: the portrait of Saint Gregory the Illuminator, the founder of the Armenian Apostolic Church (A.D. 239-325/6), and the first official head of the Armenian Apostolic Church (since 302). The sequence of miniatures of this Amulet begins with a scene of the temptation of Adam and Eve in the Garden of Eden, followed by the adoration of the Magi. Through these two subjects, the miniaturist seems to have emphasized the well-known connection between the Old and New Testaments: Adam - Christ (New Adam), Eve - Virgin Mary (see Appendix 1, I-II). Then there are images of the most powerful intercessory saints in the Armenian tradition: Saint Mother of God with Child Jesus in Her arms, John the Baptist, Saint Stephen the Protomartyr and Saint Gregory the Illuminator (see Appendix 1, III-VI). They are followed by miniatures representing the sacrifice and salvation of human sins: the Crucifixion of Christ, the apocalyptic scene - the Lord, the twelve Apostles and the Lamb of God in the centre, and the Sacrifice of Isaac (see Appendix 1, VII-XII). The prayers of protection from the evil forces are accompanied by images of the archangel Gabriel, the saviour of the deceased, of archangel Michael, the dragon-slayer, and Saint Sargis (Sergius), a saint widely venerated by the Armenians for his swift help (see Appendix 1, XIII-XV). The function 
of the Archangel Michael fighting the dragon was widespread throughout the Christian world, while the depiction of the two other saints has an interesting interpretation in Armenian tradition. According to the Armenian version of the Lives of the Saints, the worship of the Archangel Gabriel by the Armenians is known for the fact that he brought about the salvation of people, being the courier of the heavenly king (Awgerean 1810, 804-5). The Holy Scriptures describe the Last Judgement with seven angels, to whom were given seven trumpets (Revelation 8:2). One of these angels is the Archangel Gabriel, and in Armenian miniature art, his image is depicted in front of the resurrecting dead, sometimes accompanied by the inscriptions "the trumpets of Gabriel are blowing", "Gabriel's trumpet”, etc. (Sargsyan 2018: 149-50). Such a mission given to the Archangel Gabriel helps to interpret his role in this miniature as the saviour of the deceased. The other saint, Sargis, is depicted on horseback. It is known that Saint Sargis, after leaving Cappadocia, received the hospitality of the Armenian king, Tiran, and then, together with his son Martiros, ${ }^{7}$ he was moved to Persia, where he was tortured and buried in the city Hamian (late 362 or early 363 A.D., Awgerean 1810: 116, 124). Later, as the Armenian version of the Lives of the Saints testifies, Mesrop vardapet Mashtots, the founder of the Armenian alphabet (405 A.D.), moved the body of Saint Sargis to Armenia and reburied it in the city called Karbi (Awgerean 1810: 124). The same source testifies that the veneration of Saint Sargis was widespread not only among Armenians, but throughout the entire Christian East (Awgerean 1810: 124). The last miniature (see Appendix 1, XVI, ill. 1), the image of a saint chiding with an al (a demon), completes the theme of protection from evil forces.

These miniatures are simple in terms of artistic expression and iconography, but they contain some interesting details, from among which we will discuss the image of a saint fighting a demon alongside a Prayer for the disappearance

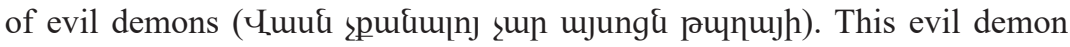
called in Armenian al (ul) is known as a creature that is harmful to childbirth and new-borns (Harutyunyan 2006: 302). Father Łewond Ališan and Frederic Feydit studied the interpretation of the word al. According to Father Ališan al or als means a deep abyss and is originated from the Germanic word "hell", which in Armenian is "ndnup" (Ališan 1895: 222). Feydit, in his turn, provides a broader study of the meaning of the word. He agrees with linguists Hračya Ačarian and Stepan Malxaseanc, that the word al has no Armenian origin and is related to the Iranian word al, which means red (Feydit 1973: 230). The author 
also draws parallels between the Armenian demon al and folkloric beliefs from other cultures. He identifies it with Iranian or Kurdish Albasti, the Romanian Avestitza or Alvestitza (Feydit 1973: 237, Mazilu, Timotin 2017: 528-42), Egyptien Alabasdria and others (Feydit 1973: 233-40). In contrast to the beliefs of various Balkan, Slavic, Arab and other peoples, where this demon appears as a female evil creature (Lyavdanski, Toporkov 2017: 13), in the Armenian tradition al seems to be a male demon, since in medieval Armenian handwritten incantation prayers very often it is described as "a man ..." (ujp ư ..., (Ališan 1895: 224, Harutyunyan 2006: 306). Incidentally, it should be noted that in the later folklore tradition, al always appears as a female cannibal creature that could transform into various animals (Harutyunyan 2006: 306). ${ }^{8}$ This folkloric belief can also be explained by the use of synonyms given to als as female evil mythical spirits: uц uщunuul (ali-crone) (Tadevosyan, Kotsinyan 2017:

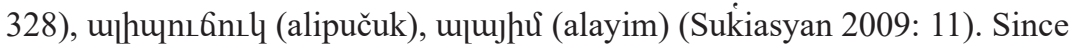
our Amulet with its text and illustration has a structure typical for medieval Armenian amulets, and given the continuity of medieval Armenian amulets till the 18th century, we tend to think that we are dealing with a male demon al.

The depiction of this demon and of the saint is extremely important for understanding the function of this Amulet. Armenian painters portrayed demons in various iconographic forms. From this point of view, rich material is represented by the drawings of a manuscript created in 1616 (Venice, Bibliotheca Marciana, Ms. Nr. 210), which contains 72 images of demons with textual descriptions (Macler 1928: 29-42, figs. 310-77). It is noteworthy that none of these images exactly correspond to the image of the demon we are interested in. ${ }^{9}$ In some cases, there are goat-headed figures (e.g. Macler 1928, figs. $317,322,339,354)$. In the Amulet described here, the artist depicted the image of a demon standing upright, with a goat's head and brass fingernails, although it is described in the text as follows: and he looked like a wild-boar (le th untuhl \&nnu hppl lupuqh ...). Similar images of al can be found in other amulets, for example in the Amulet A.D. 1724 (Library of Armenian Catholicosate of Cilicia in Antelias, Ms. Nr. 238) or in an Amulet of the Library of the Dudean Cultural House in Bucharest (Ms. n. 17) (Ghazaryan, Sargsyan 2016: 22). Father Ališan presents two reproductions with such iconography of the demons calling them tpła and al, without mentioning the source (Ališan 1895: 221, 223). 
How can we explain the depiction of the goat as a symbol of evil forces? The image of the goat is well-known since pre-Christian art. According to T. Wildridge when the pagan Gods were skilfully turned into Christian devils, we find the goat as a Satanic form (Wildridge 1899: 73). In the Armenian oral tradition, there is a remarkable description of a goat in the Armenian oral epic Daredevils of Sassoun (or David of Sassoun). ${ }^{10}$

The Great Idol in the guise of a goat,

Came over his head and began to grunt;

He would not let him sleep all night.

This he kept up for a month.

At the end of the month,

Baghdasar became sick with jaundice and was morose. ${ }^{11}$

In this epic one can read 'devas' as a synonym for the word 'idol'. ${ }^{12}$ And it is noteworthy that with the appearance of the Idol Baghdasar became sick. The words tpłutiwn and tpłotel, which come from the word tpła, were used as synonyms for illness and to get sick in Armenian (Feydit 1973: 228; Malxaseanc 1944: 127). According to Father Ališan, tpła always appears with the evil force called al (Ališan 1895: 222).

The depiction of evil ones in the form of a goat can also be explained by the Gospel text: "But when the Son of God comes in His glory ... He will separate them [all the nations] one from another as a shepherd separates the sheep from the goats. He will set the sheep on His right, but the goats on the left" (Matthew 25:31-33). ${ }^{13}$ So, in Christian understanding, the image of the goat is identified with the sinner, which itself coincides with the evil forces.

$\mathrm{Al}$ is usually depicted holding a "knife made of iron" (knlıp lunnng) in his hand (see Harutyunyan 2006: 137, 1(159) XVII 4). In our miniature, he seems to have two sacks in his hand, which is probably a symbolic depiction of the lungs described in the text, which is the food of the al:

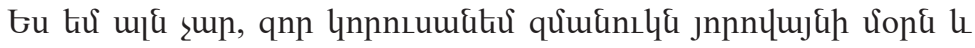

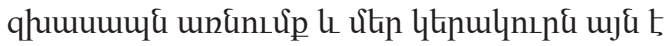

I am the evil al who looses the baby in the mother's womb, takes the lungs, and that is our food. 
The lungs are more clearly visible in the hand of a lord of demons in the Amulet of DAOB, Pr. n. 14, ill. 2.

The text mentions the names of three saints: Peter (Thunnnu), Paul ( Tnnnu) and Silas (Ghnu). Who is depicted in this miniature from these three saints? Very often, the saint fighting against the demon is Saint Sisinnius in Greco-Byzantine, South Slavic and Romanian magic literature, while the name of Saint Sisinnius occurs only sporadically in Aramaic, Syriac, Hebrew, and in Jewish traditions (Lyavdanski, Toporkov 2017: 14). Other saints also act in Christian charms, and one of them is the Archangel Michael (Badalanova Geller 2015: 178-9). In the Armenian tradition, both Saint Sisinnius and the Archangel Michael, along with other saints are known as protectors of a newborn child from the demon (Tadevosyan, Kotsinyan 2017: 333-5). The only saint depicted in the miniature presented here is Saint Peter, whose name is mentioned first in the text. Saint Peter pulls the beard of the evil demon with one hand, and with the other brings the sword close to the demon, as if cutting its beard. The sword is like tongues of fire. A similar topos can be found in various Armenian charms:

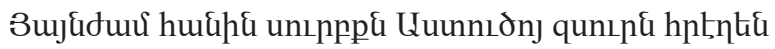

At that time the saints of God drew their fiery sword (Harutyunyan 2006: 131, 1(159) IV 25).

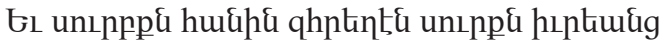

And the saints drew their fiery swords (Harutyunyan 2006: 132, 1(159) V 31).

The use of the sword in order to protect the new-born child or the woman in labour found an interesting interpretation in the ethnographic material. In the Armenian folk tradition of childbirth, it was customary to place a sword next to the bed or under the pillow of the woman in labour to protect the baby's crib or the four walls of the room from evil forces (Harutyunyan 2006: 302-3).

The gesture of pulling the beard of evil is an interesting detail. It is depicted in various arts, also in Armenian, and there are different interpretations of its meaning (Endoltseva, Vinogradov 2016: 88-98, Jacoby 1987: 65-85). The role of the beard pullers is mainly played by secular people with negative characteristics or people with positive characteristics, sometimes even saints (Endoltseva, Vinogradov 2016: 90). In this miniature, we are dealing with the 
latter version, but the saint does not pull the beard of a man, which is often found in the iconography; instead, he pulls the beard of a goat in the role of an evil al. Considering that a beard is also an expression of sin and impurity (Jacoby 1987: 65), it can be assumed that the saint, pulling the beard of evil and drawing the sword closer to him, is trying to chide and kill the evil al. The meaning of beard pulling is interpreted in the Armenian national epic Daredevils of Sassoun. According to the epic poem, the Caliph of Baghdad, a negative character, notices the growing power of Sanasar and Baghdasar, two brothers with positive attributes, and says to himself: "I know that when they grow up they will hang from my beard and cause me no end of trouble". ${ }^{14} \mathrm{Of}$ course, in this description the gesture is not repeated directly as in the miniature, but the pulling of or hanging from the beard represents the same action.

\section{THE EARLY PRINTED AMULETS IN SCROLL}

Just like early printed Armenian books, Amulets in scroll form are of special interests by virtue of both their contents and their form, which derives from the tradition of Armenian handwritten scroll-shaped Amulets (Ghazaryan 2018a: 70). Usually, the contents of early printed Armenian Amulets represent prayers to various saints and passages from the Gospels. ${ }^{15}$ These texts are decorated with scenes illustrating the Holy Scriptures (Ghazaryan 2018a: 70). Currently, the number of identified Armenian early printed Amulets between 1659 and 1731 is eighteen, and they were produced in four printing houses: three in Constantinople and another one, the location of which is unknown (Ghazaryan 2018a: 69-99, Ghazaryan 2013b: 13-14, Ghazaryan 2018b: 73-85). It is possible that new Amulets may appear in the future, which will enrich our knowledge about early printed Armenian Amulets.

The Pr. n. 15 (Appendix 2) was printed in 1716 (Armenian era 1165) in the publishing house of Grigor Marzvaneci in Constantinople. There are missing parts at the beginning and in the middle of the Amulet. This happens very often with Amulets, as they were held by the owners and repeatedly re-read for ritual purposes.

We do not know of any completely preserved example of this Amulet. Originally, it would be over $660 \mathrm{~cm}$ in length. The Amulet is decorated with eleven engravings ${ }^{16}$ (Appendix 2, I-XI), five headpieces and nine ornamented letters. These gravures belong to the first Armenian engraver Grigor Marzvaneci. ${ }^{17}$ Six Amulets in scroll are known from the printing house of Marzvaneci. ${ }^{18}$ 
The amulet consists of sixteen prayers 19 and some of these texts are accompanied by engravings describing the text.

The second printed Amulet (Pr. n. 14, Appendix 3) was printed by an unknown printing house at the second half of the 19th century. It is decorated with twenty-three gravures (Appendix 3, I-XIII), and two headpieces: one with three angels on their knees in a gesture of prayer, and the other with two angels on their knees leaning on the tomb of Christ. The Amulet consists of thirty prayers.

Altough the date 1717 (A.E. 1166) is mentioned in the colophon of the Amulet,20 there are several reasons to question the date stated in the colophon:

1. The paper of the Amulet is very thin, without watermarks or waterlines. Such paper is typical of the second half of the 19th century.

2 . The letters and the style of printing are not typical for the early printing period of Armenian book production (1512-1800). They are closer to the printed products of the 19th-20th centuries.

3. Another important argument, which allows us to assign the date of the Amulet to the 19th century is the signed European-style gravures. Some of them are signed: "Laurent et De Berny" (ill. 3). These gravures were engraved in the Deberny printing house in Paris. The Deberny house is the heir to Balzac's printing project, a project that he financed thanks to Madame Louis Antoinette Laure De Berny in 1826.2

Below are the descriptions of the above-mentioned handwritten and early printed Amulets in scroll.

\section{Appendix 1}

Armenian Orthodox Diocese of Baghdad, Iraq

Ms. n. 13

AMULET IN SCROLL

ARZRUM (=ERZRUM, KARIN)

OWNER: Ohan.

MATERIAL: paper. SIZE: $699.4 \times 10-10.5 \mathrm{~cm}$ (composed of 15 pieces 22 (14. $4+15.7+49.5+18+53.4+47+48.5+48.5+36.6+60+60.5+61+61.8+57+34$ $.5)$ glued together). WRITING: one column $(7.8-8 \mathrm{~cm})$. SCRIPT: notrgir.23

ILLUMINATION: Colours: red, green, blue, orange, rosy, violet, brown, black, bronze (partly missing) and silver (partly missing). 
STATE: Satisfactory. The amulet is incomplete and there are losses at the beginning and at the middle. The edges of the Amulet are worn. The manuscript was restored at the end of the 19th century, during which a cloth was glued along the verso of the Amulet.

\section{CONTENTS AND ILLUMINATIONS}

\section{III \\ I. The Adoration of Magi \\ I/I \\ II. The Temptation of Adam and Eve}

Note: The miniature II must be before the miniature I. It has been glued on the wrong place during restoration undertaken at the end of the 19th century.

1. [Prayer of Nerses Shnorhali - "In faith I confess"] ... to the servant of the God Vardan (19th century, shłagir).

[Unopp untiund Gtiputu hujpumbinp uumgtiul - <usuinnl

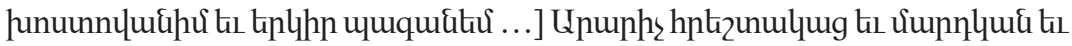

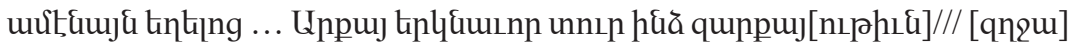

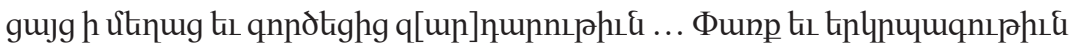

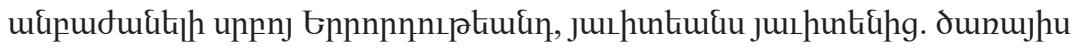

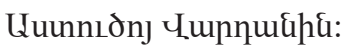

Note: The unit, except the end, is divided into 14 rhombuses and a triangular part. The parts have vegetal decorations.

2. Gospel of Saint Matthew (15: 21-28)

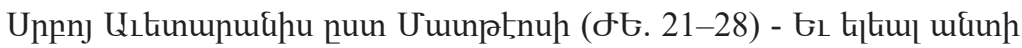

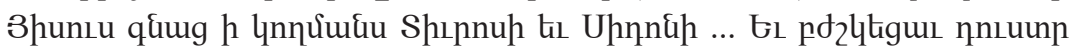

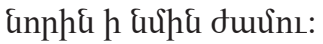

3. Gospel of Saint Mark (1: 1-8)

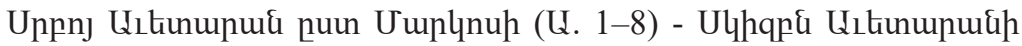

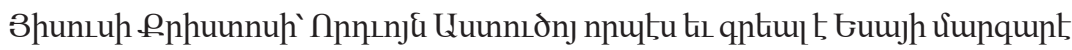

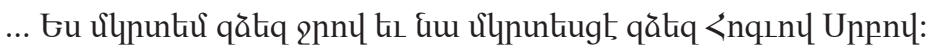

4.Gospel of Saint Luke (9: 37-44)

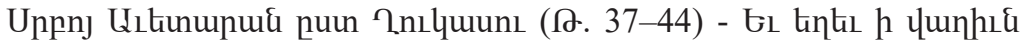

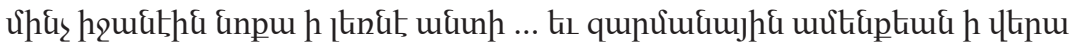

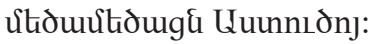


5. Gospel of Saint John (4: 43-54) ... Help Vardan. Amen (19th century, shłagir).

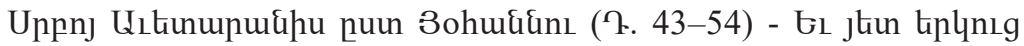

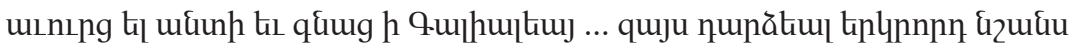

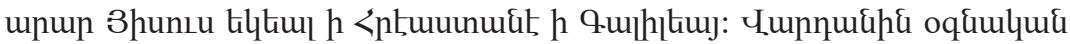
tinhg. units:

III. Madonna with the Child Jesus in Her arms

6. Prayer to Madonna ... always help and protect the servant of the God Vardan (19th century, shłagir) ... Amen.

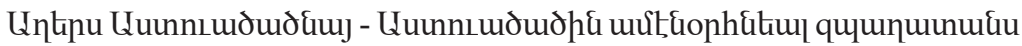

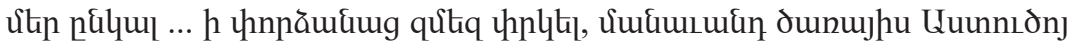

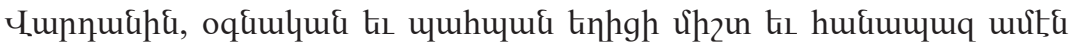
dưưnt. ư⿰彳ॄ:

IV. Saint John the Baptist.

7. Prayer to John the Baptist ... protect and save the servant of the God Vardan (19th century, shłagir).

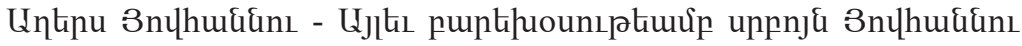

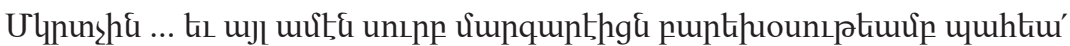

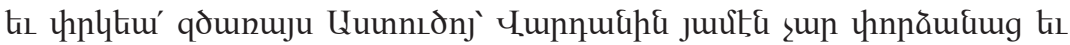
nnnqujphg. uर्uta:

V. Saint Stephen the Protomartyr.

8. Prayer to Stephen the Protomartyr ... to the servant of the God Vardan (19th century, shłagir).

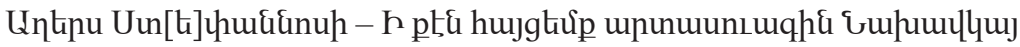

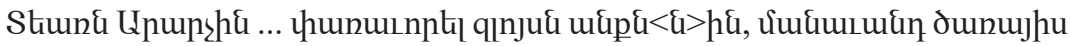

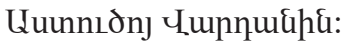

VI. Saint Gregory the Illuminator.

9. Prayer to Gregory the Illuminator ... to the servant of the God Vardan (19th century, shłagir). Amen.

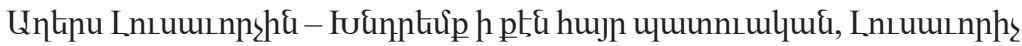

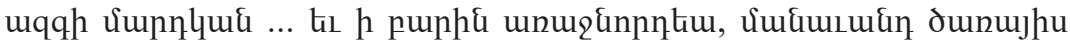

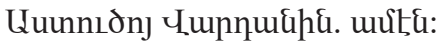

Note: The units 6-9 and the miniatures III-VI are into the circles. The parts, which are out of circles, have vegetal decorations.

VII. The Crucifixion 
10. Prayer against the spells of demons and witches and sects, and for the successful judgment and pleasure and lucky.

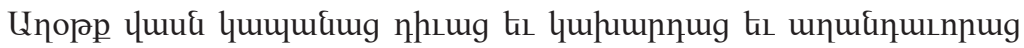

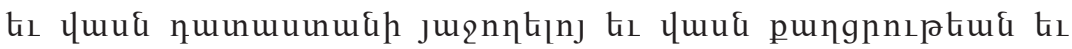

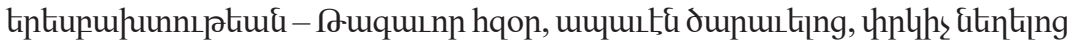

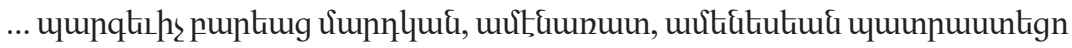

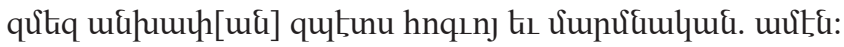

VIII. The Lord

IX. Six apostles

X. The Lamb of God

XI. Six apostles

Note: The miniatures VIII-XI are in circles surrounded by floral ornaments. The apostles are in twos in every line.

XII. The sacrifice of Isaac

11. Thanksgiving to Saint Abraham and to the Lord's saint signs ... protect the servant of the God Vardan (19th century, shłagir). Amen.

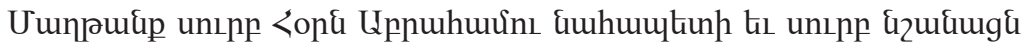

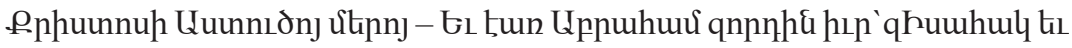

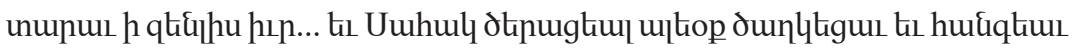
humnunnıptiuúp h ephuunnu:

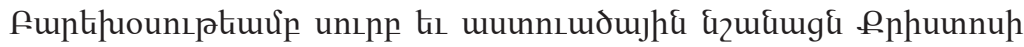

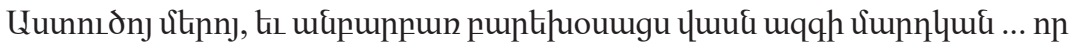

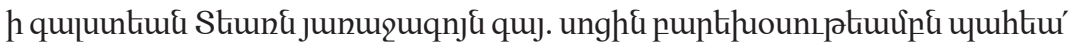

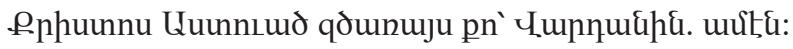

Note: item 11 consists of two prayers, which are written in slanting-intersecting lines, except the title and the end of second prayer. The rhombuses, which emerge from the slanting-intersecting lines, are decorated with floral ornaments.

XIII. Archangel Gabriel takes the soul of the deceased

12. Prayer to Archangels for the protection ... to the servant of God Vardan (19th century, shłagir).

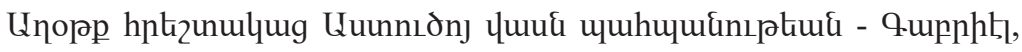

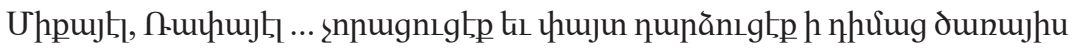
Uuunnıdnj Ч.upnuîhq:

13. Prayer for lucky travel 


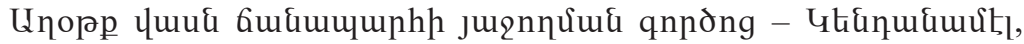

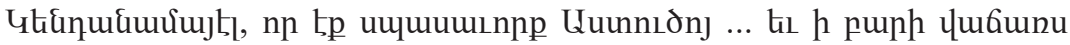

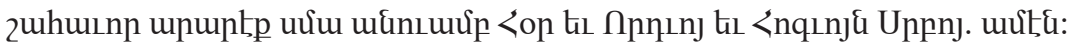

14. Prayer against the evil fear and the evil tongue ... the servant of the God Vardan. Amen (19th century, shłagir).

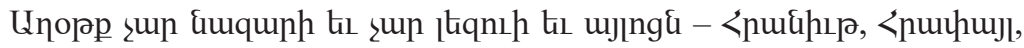

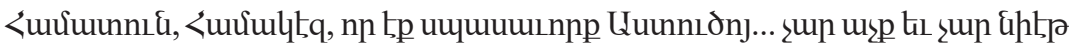

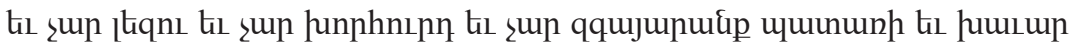

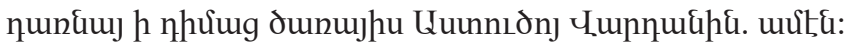

15. Thanksgiving to the holy kings ...protect the servant of the God Vardan, and help him. Amen (19th century, shłagir).

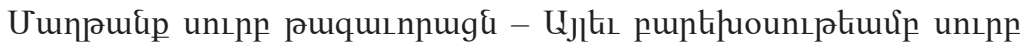

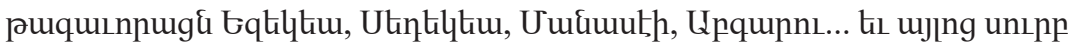

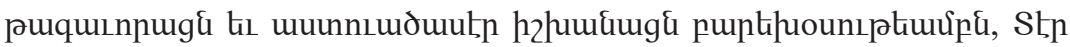

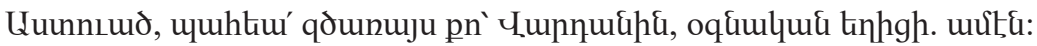

16. Prayer to the Holy Pokas patriarch... save your servant Oh[an] (the name of the first owner is erased by ink-line) Vardan (19th century, shłagir) from all dangers.

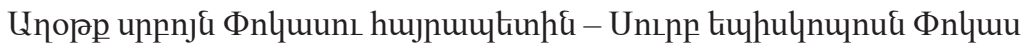

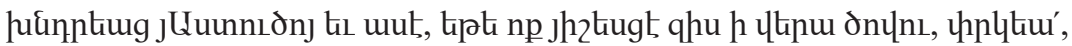

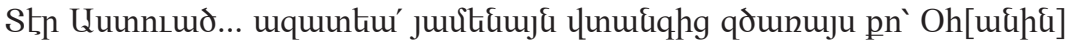
Ч.upnuîh:

17. Prayer for lucky speech and business... to your servant Vardan (the name is written upon the name of the first owner, 19th century, shłagir) ... Vardan (19th century, shłagir).

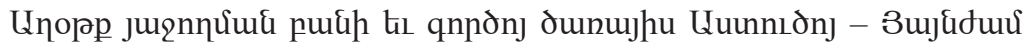

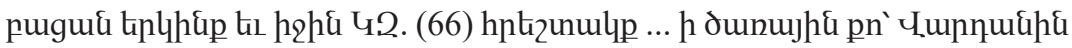

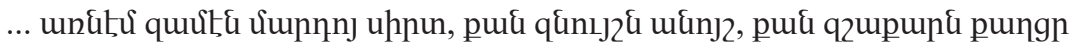

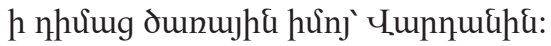

XIV. Saint George on horseback slaying the dragon

18. Prayer to Saint soldier George... protect the servant of the God Vardan (19th century, shłagir).

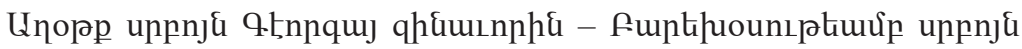

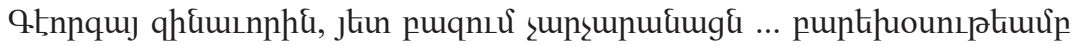

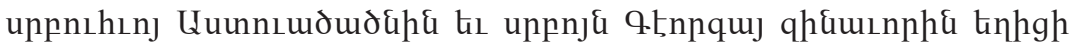

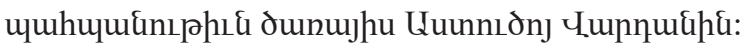


19. Prayer for childbirth ... give a child to your servant Vardan (19th century, shłagir).

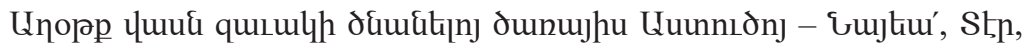

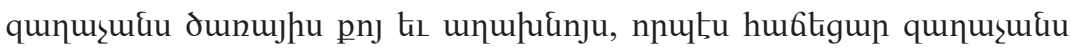

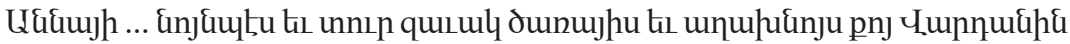

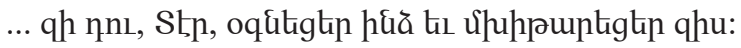

20. Prayer for pain in the eyes ... enlighten the eyes of your servant Vardan (19th century, shłagir).

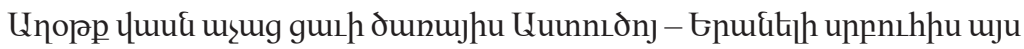

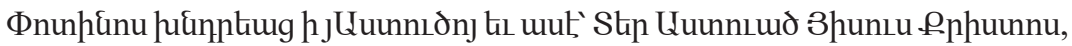

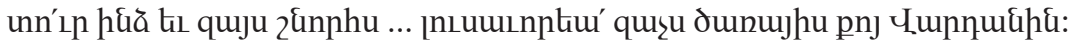

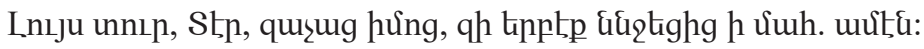

XV. Saint Sargis on horseback

21. A wish for Saint Sargis General and his son Martiros... protect the servant of the God Vardan (19th century, shłagir).

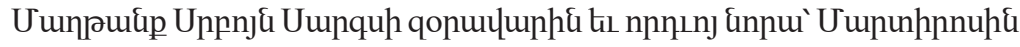

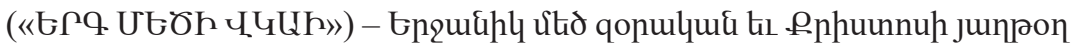

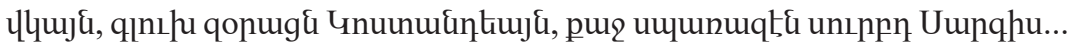

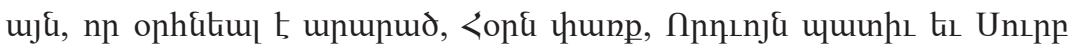

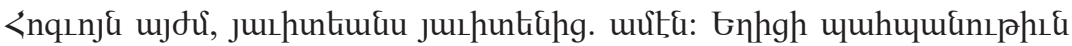

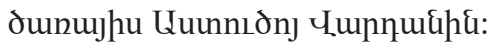

XVI. Saint Peter chides the demon - al.

22. Prayer for disappearance of evil demons ... and do not enter the house, especially the house of the servant of the God Vardan, Amen (19th century, shłagir).

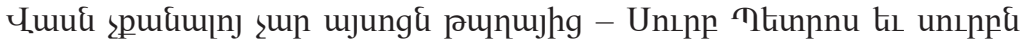

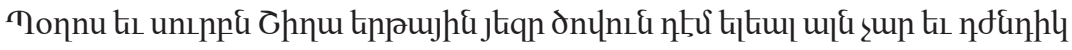

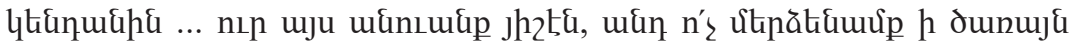

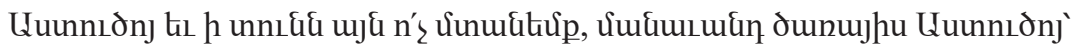

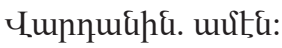

23. Prayer for persecuting the evil demon and the evil devils... the servant of the God Vardan (19th century, shłagir).

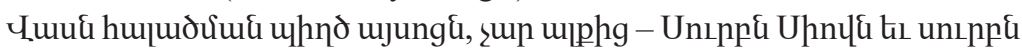

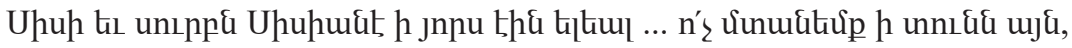

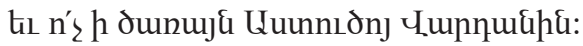

24. Prayer of Saint Gregory of Narek (Extract from "Book of Lamentations", Chapter 41) for protection from nocturnal horrors. 


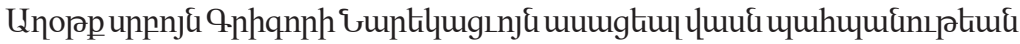

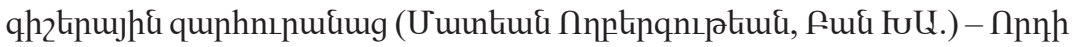

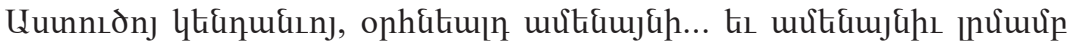

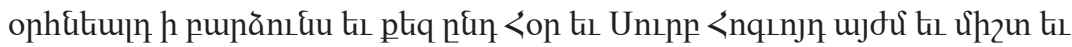

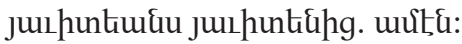

25. Prayer for the protection of the servant of the God ... The servant of the God Vardan (19th century, shłagir).

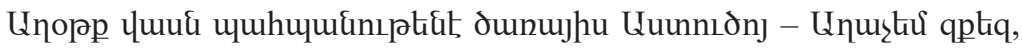

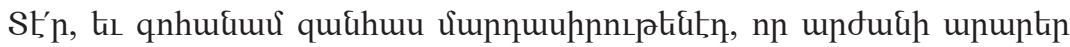

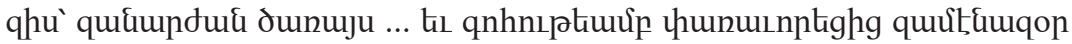

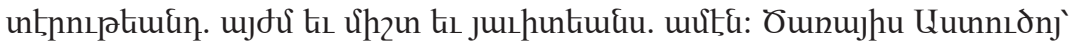
ч.upnuqupq:

26. Prayer of Saint Gregory of Narek (Extract from "Book of Lamentations", Chapter 94) for protection from nocturnal horrors ... the servant of the God Vardan /// (one line was erased). Amen (19th century, shłagir).

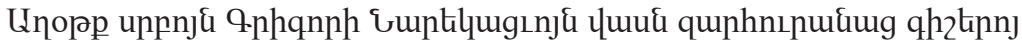
(Uuuntiud กnptipqnıptiud, fud २..) - Luunnsud jushuntiulyud,

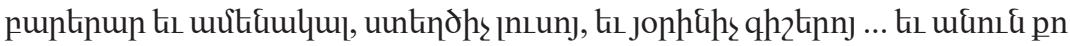

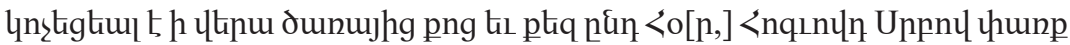

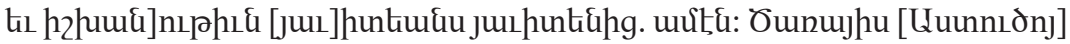

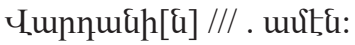

\section{COLOPHON ABOUT THE TIME OF WRITING BY THE SCRIBE}

"The holy protection letters (=Amulet: one of the synonyms of the name in Armenian tradition) were rewritten in 1195 of the Armenian era (=1736) in the city Arzrum".

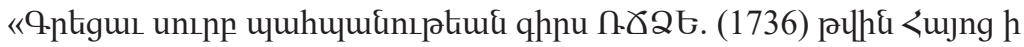
punupu Unqnnıu»:

ANNOTATION: At the 2nd piece in marginal part: "DAOB-00013". At the beginning of verso, glued: rectangular, printed in 3 colours (red, blue and

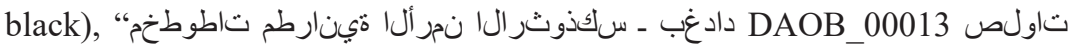
ةمعنل عولجم سيسرن سيدقال (arabic, Manuscripts of the Armenian Orthodox Diocese of Baghdad / DAOB_00013 / The prayers of Saint Nerses Shnorhali,24 Centre Numérique des Manuscrits Orientaux Dominicains - Mossoul - Fondé 
en 1990". At the beginning of the verso, on glued paper with black pencil we find: “GDz 1" (૧ă 1).

\section{Appendix 2}

Armenian Orthodox Diocese of Baghdad, Iraq

Pr. n. 15

AMULET IN SCROLL

(early printed)

\section{[CONSTANTINOPLE]}

PRINTING HOUSE, ARTIST: [Grigor Marzvaneći]. OWNER: Melkon.

MATERIAL: paper. SIZE: 348x10 cm (composed of 9 pieces: 22.9+40. $8+40.3+40.3+40.8+40.3+40.3+40.3+42)$. WRITING: one column $(8.5 \mathrm{~cm})$. SCRIPT: bolorgir ( 8 dpi).

Note: For the size of the Amulet is used another Amulet of the same publishing house (early printed Amulet in scroll, Pr. n. 19, Matenadaran).

ILLUSTRATION: Ornamented letters: bird-shaped (eight), zoomorphic (one).

Note: Subsequently, the engravings are partially coloured in blue, yellow, orange, pink (discoloured), brown, and the marginal parts are partially coloured in yellow.

STATE: Satisfactory. The printing is incomplete and there are missing parts in the beginning and in the middle. The edges of the beginning of the Amulet are worn. The paper gradually changes its colour and becomes yellowish with moisture. Now the Amulet composed of nineteen separate pieces.

\section{CONTENTS AND ILLUMINATIONS}

$/ / /$

1. Gospel of Saint Luke (6:19) ... And protect the servant of God.

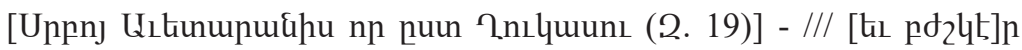

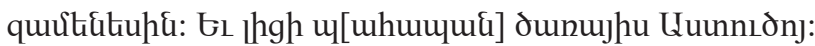

Headpiece

2. Gospel of Saint John (5: 1-9) ... And protect the servant of God Melkon (notrgir). 


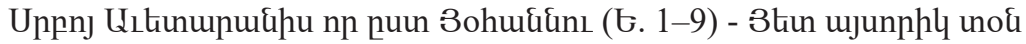

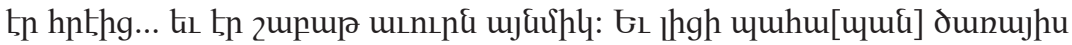
Uuunnıðnj Uלןpoh氏:

Headpiece

Note: The left part of the headpiece is lost.

3. Excerpt from Gregory of Narek "Book of Lamentations" (Chapter 12) ... Melkon (notrgir). To Alas and his sons (19th century, notrgir).

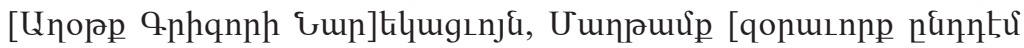

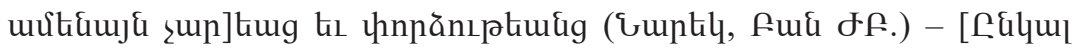

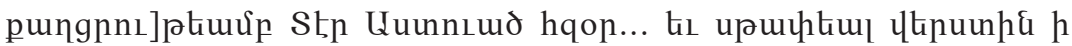

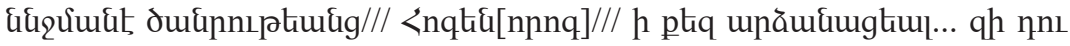

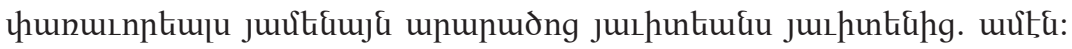

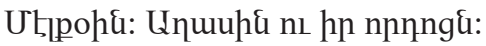

I. The Lamb of God

II. 12 apostles

Note: The miniatures I-II are into the circles. The apostles are in twos in every line. The parts that are outside the circles represent vegetal decorations.

4. [Prayer to the saint apostles] ... And protect Barseł, Guhar's Zirō, Ałas, Melkon (notrgir), Karapet, Hakō, Suxō, Gaŕux, Sargis (19th century, notrgir).

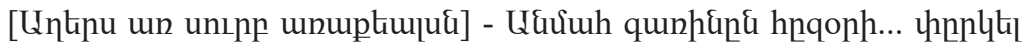

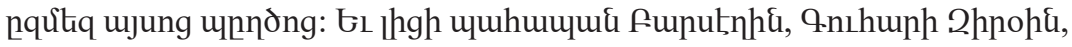

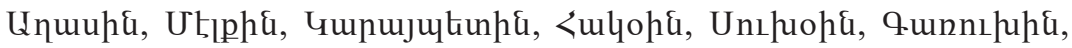
Uupqhuhq:

Headpiece

5. Excerpt from Gregory of Narek "Book of Lamentations" (Chapter 41) ... And protect the servant of God Melkon (notrgir).

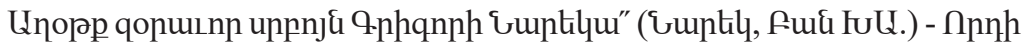

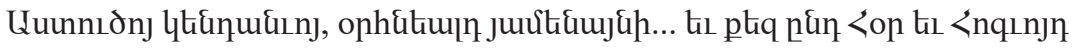

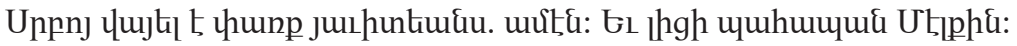

III. Madonna with the Child Jesus in her arms

6. [Prayer to the Madonna by Mesrop vardapet Mashtots (Matenadaran, Amulet in scroll, Ms. n. 498, 10)] ... Sargis, Ałas, Guhar (19th century, notrgir) ...

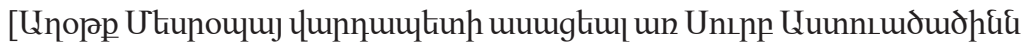

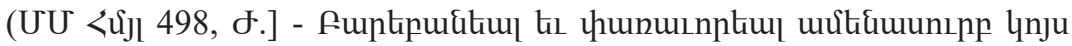

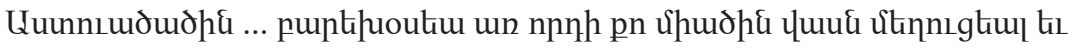




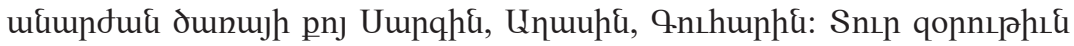

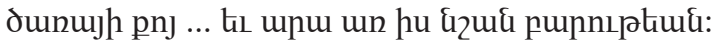

Headpiece

7. Prayer for childbirth ... and give a good child to the servant of God Ałas, Guhar (19th century, notrgir).

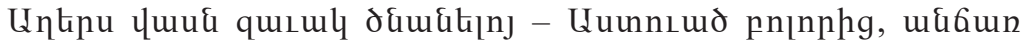

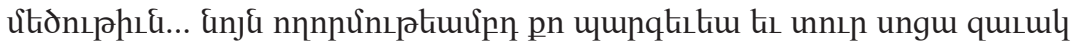
puph dunujhu Luunnıonj Unuuhf:

IV. Beheading of John the Baptist

8. Prayer to John the Baptist ... and protect the servant of God Gaŕux, Hakō, Suxō (19th century, notrgir).

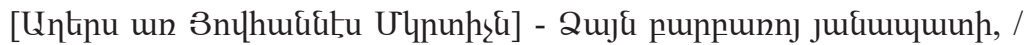

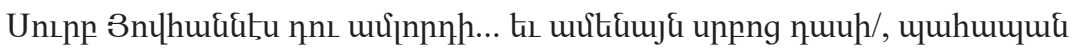

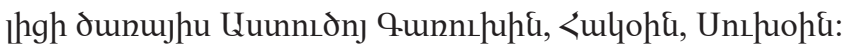

V. Saint Stephen the Protomartyr

9. Prayer to Saint Stephen the Protomartyr ... And protect Barsel, G///o, Melkon (notrgir), Karapet (19th century, notrgir).

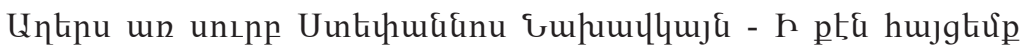

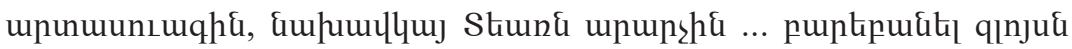

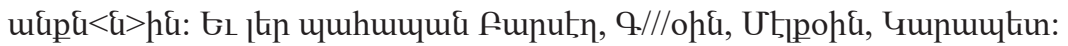

VI. Saint Gregory the Illuminator

10. Prayer to Saint Gregory the Illuminator ... protect Your servant Karapet (19th century, notrgir).

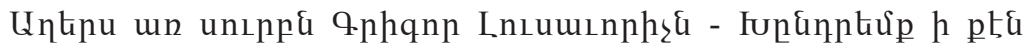

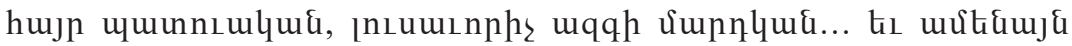

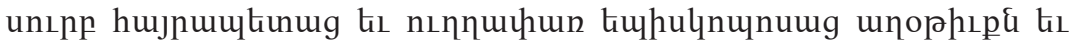

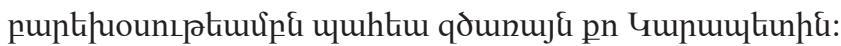

VII. Archangels Michael and Gabriel lancing the devil

11. Prayer to the heavenly soldiers ... help and protect the servant of the God Zirō (19th century, notrgir). Melkon (notrgir).

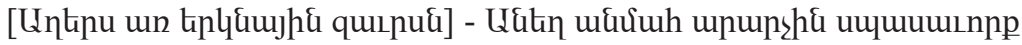

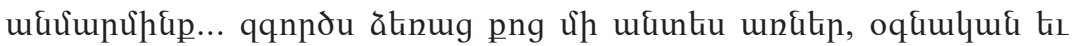

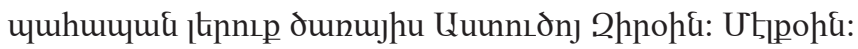

VIII. The sacrifice of Isaac

12. [Prayer of Saint Abraham] 


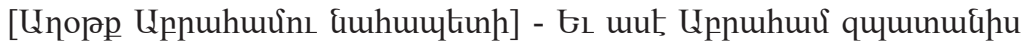

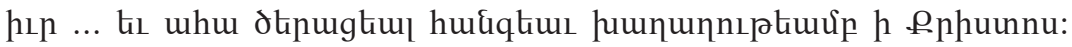

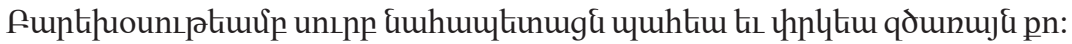

Note: The middle part of the unit is written in slanting-intersecting lines. The rhombuses, which emerge from the slanting-intersecting lines, are decorated with cross-shaped flowers.

IX. The Crucifixion (The cross is framed by wreaths)

13. [Prayer of the Holy Glorious Cross]

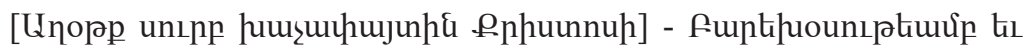

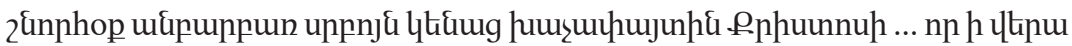

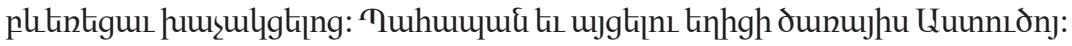

Note: The unit is written on both sides of the image in vertical lines.

$X$. Saint Sargis and his son Martiros on horseback

14. Prayer to the saint soldiers of Jesus ... protect and save the servant of God Melkon (notrgir).

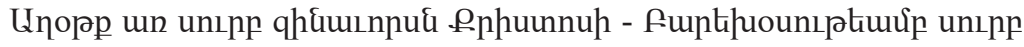

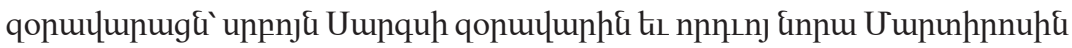

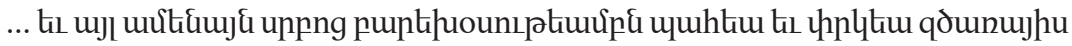
Uuunnıðnj Uhцpoh氏:

Headpiece

15. Prayer against the evil fear and the evil tongue

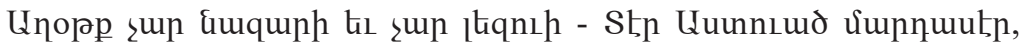

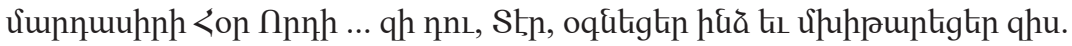
uniţa:

XI. Armed Archangel and a demon

16. Prayer against the tpła and the al who does not come near to the servant of the God ... to the servant of the God Melkon (notrgir).

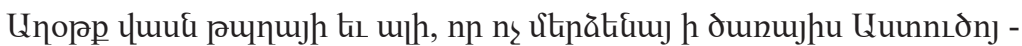

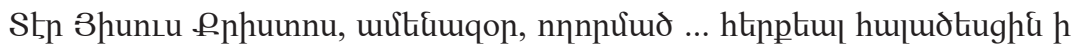

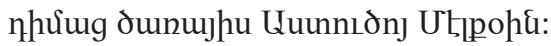

\section{COLOPHON OF THE PRINTING HOUSE}

"The Amulet was printed in 1165 of the Armenian era (=1716), in January. Also remember in your prayers Nerses the typesetter, Isaiah the paint spreader and Jacob the printer, and you, who remember us, will be remembered on the Day of Judgement. Amen. Our Father, who is in heaven". 


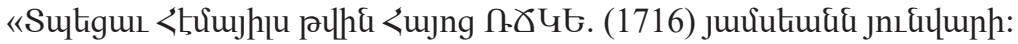

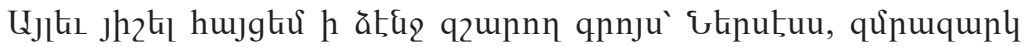

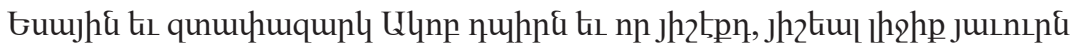

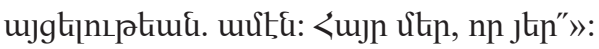

ANNOTATION: On the paper with the Amulet: rectangular, printed in 3 colours (red, blue and black), "دادغب ـ سكذذوثر الا نمر أل إثينارطم تاطوطخم DAOB_00015 ثيسقطت لمقاولص (arabic, Manuscripts of the Armenian Orthodox Diocese of Baghdad / DAOB_00015 / Ritual prayers25). Centre Numérique des Manuscrits Orientaux Dominicains - Mossoul - Fondé en 1990”.

\section{Appendix 3}

Armenian Orthodox Diocese of Baghdad, Iraq

Pr. n. 14

AMULET IN SCROLL

2nd half of 19th century

ARTIST: [Foundry Laurent et Deberny]. OWNER: Naslē.

Note: Some gravures are signed by him "Laurent et De Berny" or "LAURENT DE BERNY".

MATERIAL: paper. SIZE: 600x12 cm. WRITING: one column $(10 \mathrm{~cm})$. SCRIPT: bolorgir (7 dpi).

STATE: Satisfactory. The edges of the beginning of the Amulet are worn. The Amulet underwent restoration during which paper was glued along the entire length of the verso.

\section{CONTENTS AND ILLUSTRATIONS}

\section{God the Father}

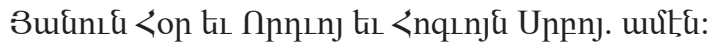

Note: This and other illustrations are accompanied by titles and explanations.
II. The Annunciation
Uıtunhud quupnhלh
III. The Nativity
бonı\&ñ 3hunıuh enhuunnuh 
IV. The Baptism

Ulnunnıphı\&u @phuunnuh

V. The Resurrection of Christ

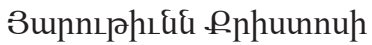

VI. The Holy Trinity

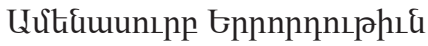

Headpiece with three kneeled angels in a gesture of praying

1. Prayer of Nerses Shnorhali - "In faith I confess" ... to the servant of God Nasle (bolorgir) ...

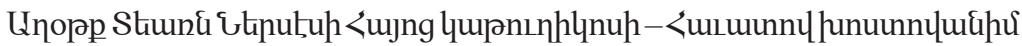

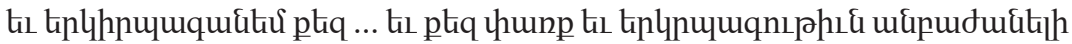

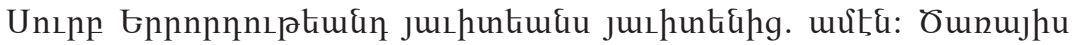

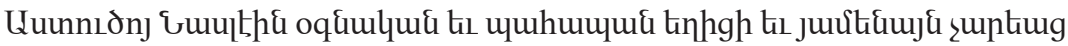
upuhtiugt tis uquintiugt. units:

2. Prayer to the Madonna ... Całik (is written on the paper, which is glued upon the name of the first owner, 19th century, shłagir) ...

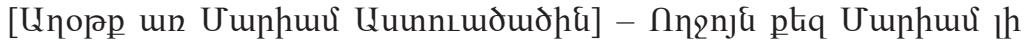

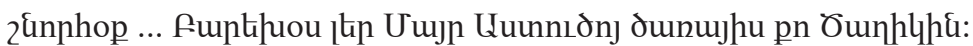

VII. The Intercession ... Naslē (bolorgir).

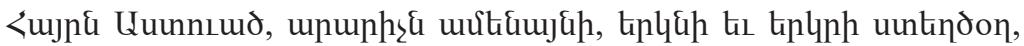

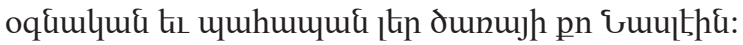

VIII. Decorated Canon Table ... Naslē (bolorgir).

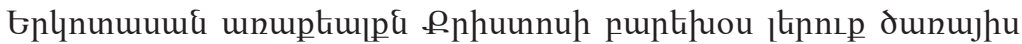
Luunnıdnj Guulthน:

IX. The Lamb of God ... Całik (is written on the paper, which is glued over the name of the first owner, 19th century, shłagir).

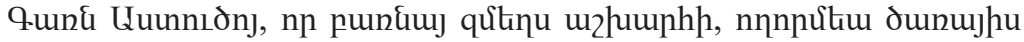

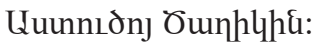

X. The chalice, two Doctrinal Wands and the Tablet ... Naslē (bolorgir).

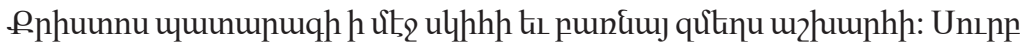

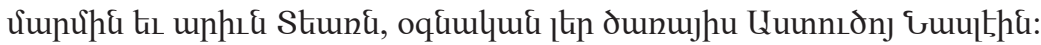

XI. The Tomb of Christ ... Naslē (bolorgir).

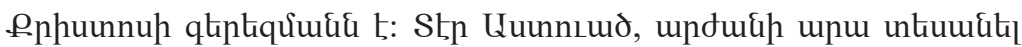

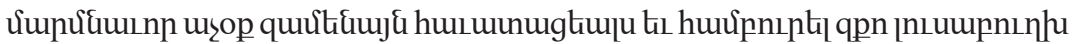
unıpp qtiptiquuiun tiı qdumuju pn Guulthu:

3. Lord's prayer 


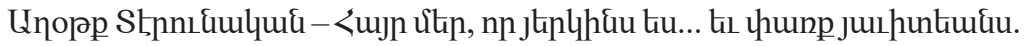
unitiu:

4. [To Holy God on a proper day] ... to the servant of God Naslē (bolorgir).

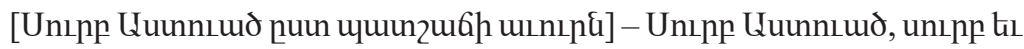

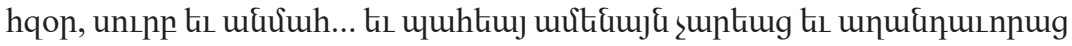
h nhर्umg dunujhu Luunnıonj Guulthk:

XII. The Crucifixion of Christ ... Naslē (bolorgir).

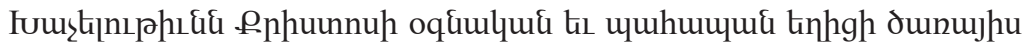
Uuunnıonj Guulthu:

Headpiece with two angels on their knees leaning on the tomb of Christ

5. Prayer against the spells of demons and witches and sects, and for successful judgment and pleasure and luck. Amen ... to the servant of God [Naslē] (bolorgir)...

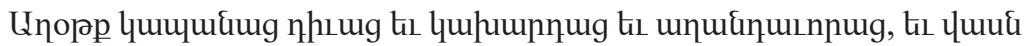

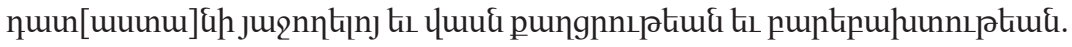

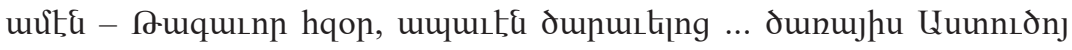

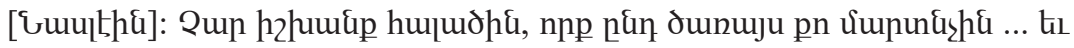
n乞 h \&itint, nn pnsh h unnıt:

XIII. Madonna with the Christ Child in her arms

6. Prayer to the Saint Virgin ... to the servant of God Całik (is written on the paper, which is glued over the name of the first owner, 19th century, shłagir) ...

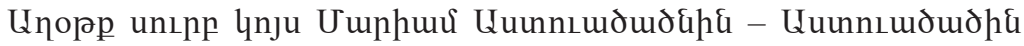

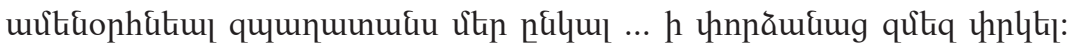

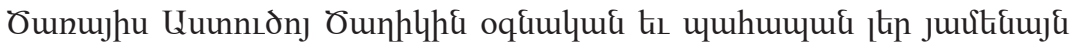
dưu. uniţ:

XIV. Saint John the Baptist

7. Prayer to John the Baptist... the servant of God [Naslē] (bolorgir).

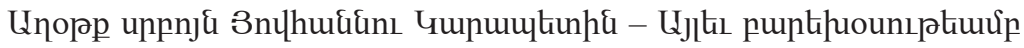

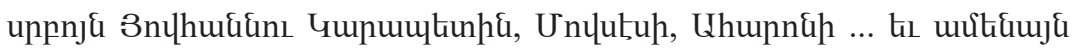

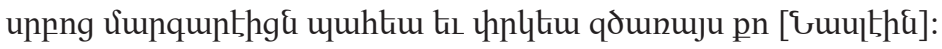

XV. Saint Stephen the Protomartyr

8. Prayer to Saint Stephen the Protomartyr

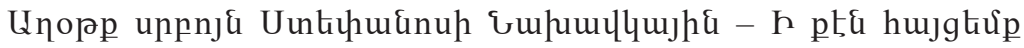

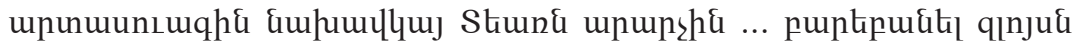

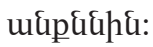

XVI. Saint Gregory the Illuminator 
9. Prayer to Saint Gregory the Illuminator

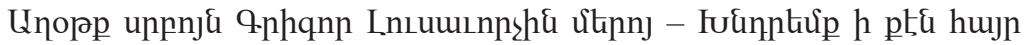

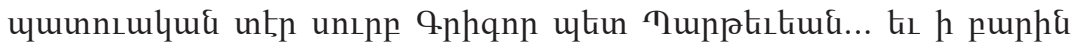

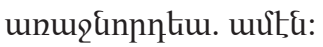

10. Prayer for protection ... to the servant of God [Naslē] (bolorgir).

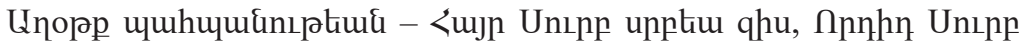

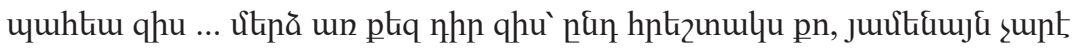
üuhtiu qdunuju pn [ษuulth氏]:

\section{Prayer for protection}

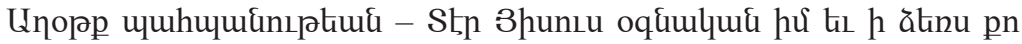

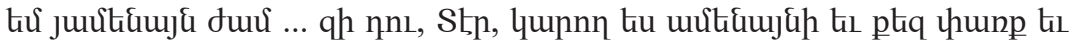

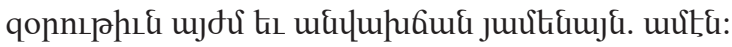

XVII. Trumpet angel on horseback

12. Prayer for the protection of Archangels Gabriel, Michael ... to the servant of God Naslē (bolorgir) ... to the servant of God [Naslē] (bolorgir).

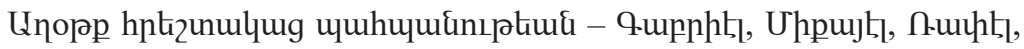

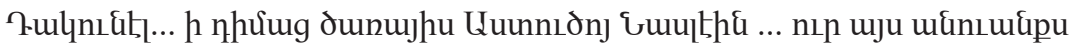

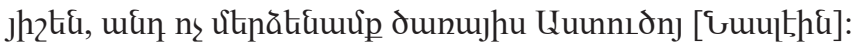

13. Prayer for headache and pain in eyes ... to the servant Całik (is written on the paper, which is glued over the name of the first owner, 19th century, shłagir) ...

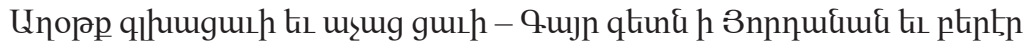

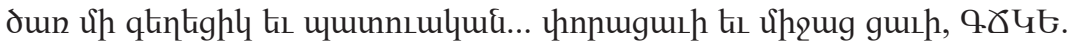

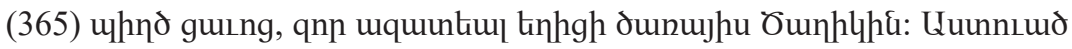

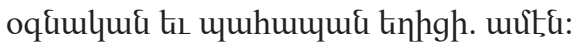

14. Prayer for protection from the evil fear and the evil tongue ... Help and protect the servant of God Naslē (bolorgir).

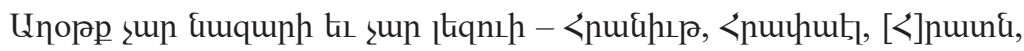

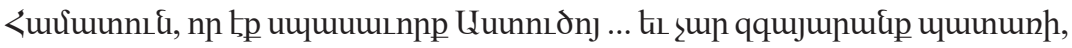

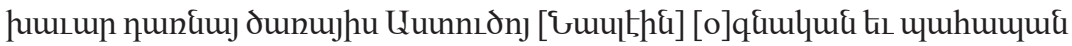
thhgh. ứt:a:

15. [Prayer against the evil fear and the evil tongue] ... and save the servant of God Naslē (bolorgir) ...

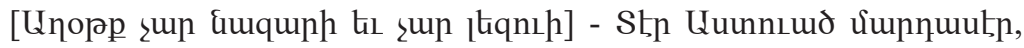

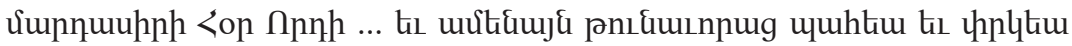

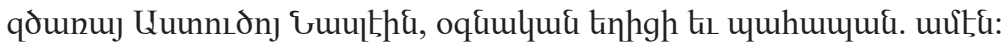


16. Prayer for the travellers ... the servant of God Catik (is written on the paper, which is glued upon the name of the first owner, 19th century, shłagir) ...

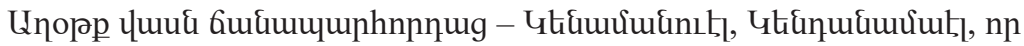

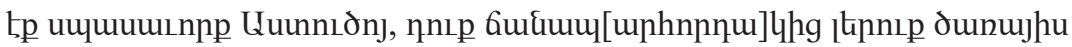

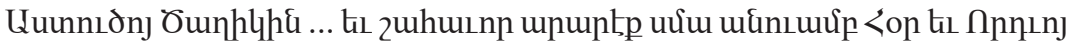

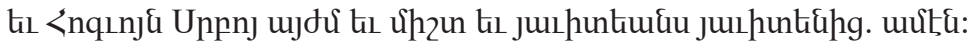

17. [Prayer of Saint Abraham and his son Isaac, and of the Holy Glorious Cross] ... Catik (is written on paper glued over the name of the first owner, 19th century, shłagir) ... to the servant of God Naslē (bolorgir) ...

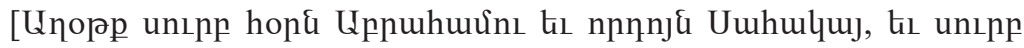

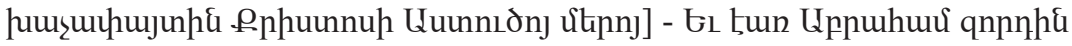

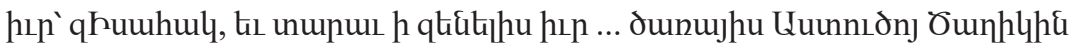

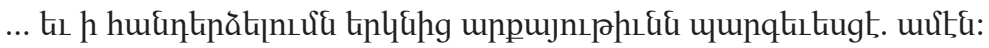

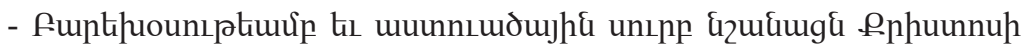

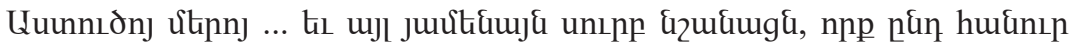

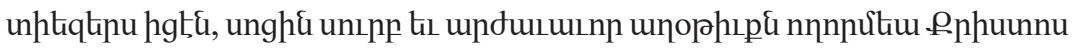

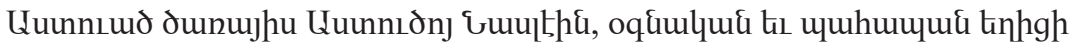

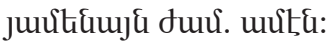

Note: item 17 consists of two prayers, the first part of which are written in slanting-intersecting lines. The rhombuses, which emerge from the slantingintersecting lines, are decorated with cross-shaped flowers.

18. Excerpt from Gregory of Narek's "Book of Lamentations" (Chapter 41) ...

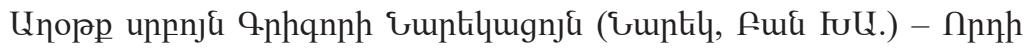

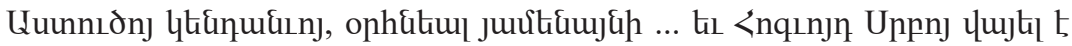

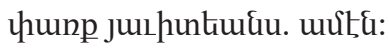

19. Excerpt from Gregory of Narek's "Book of Lamentations" (Chapter 12)

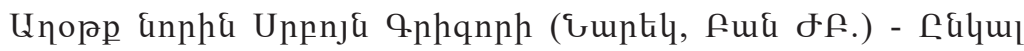

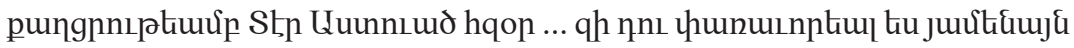

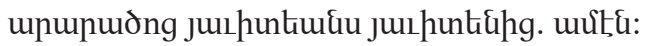

20. Prayer to Saint George the general ... the servant of God Naslē (bolorgir) ...

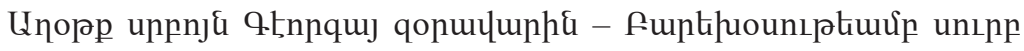

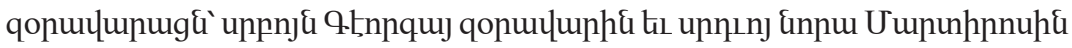

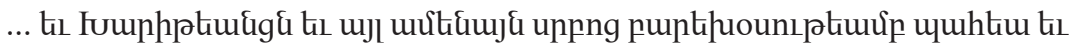




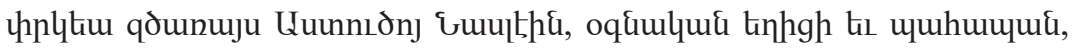

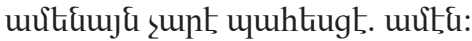

XVIII. Saint Sargis on horseback

21. Prayer to Saint Sargis the general ... help and protect the servant of God [Naslē] (bolorgir).

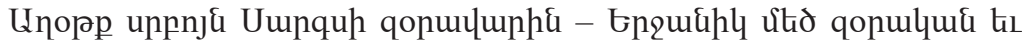

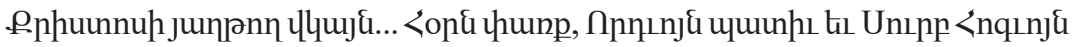

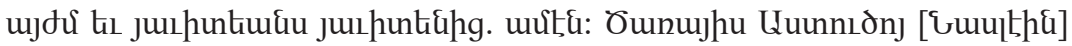

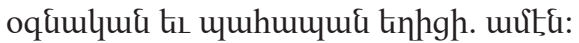

22. Prayer to Saint kings ... the servant of God [Naslē] (bolorgir) ...

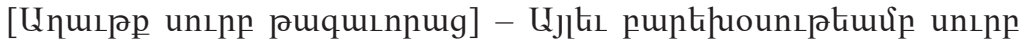

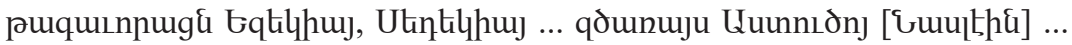
tis unu un hu đzud punnıptiud:

XIX. Saint Matthew the Evangelist

23. Gospel of Saint Matthew (15:21-28) ... help and protect the servant of God [Naslē] (bolorgir). Amen.

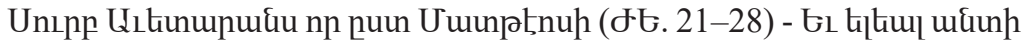

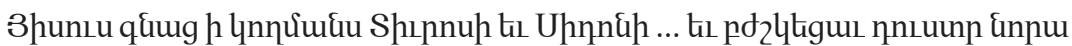

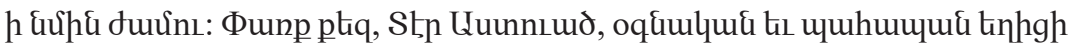

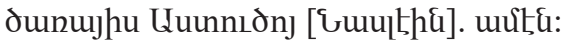

XX. Saint Mark the Evangelist

24. Gospel of Saint Mark (6: 45-56) ... Help the servant of God Na[slē] (bolorgir).

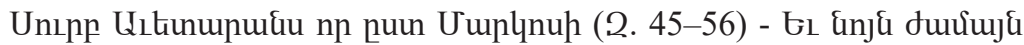

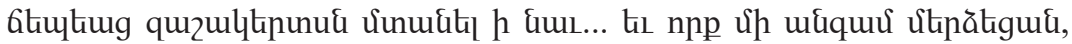

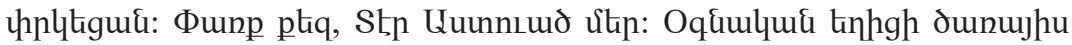
Luunnıðn] Gu[ulbh氏]:

XXI. Saint Luke the Evangelist

25. Gospel of Saint Luke (4: $31-42)$

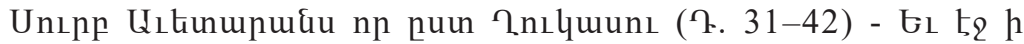

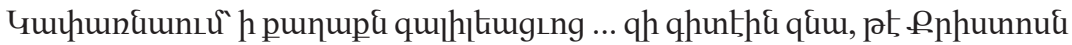
5: Фunp phiq, Stp Luunnıud ulin:

XXII. Saint John the Evangelist

26. Gospel of Saint John (6:1-14) ... help and protect the servant of God [Naslē] (bolorgir) [Całi]k (is written on the paper, which is glued upon the name of the first owner, 19th century, shłagir) ... 


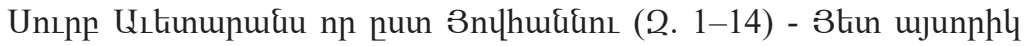

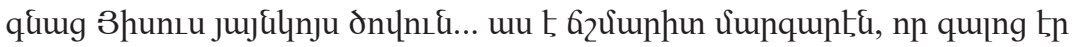

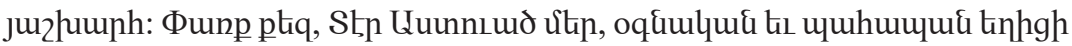

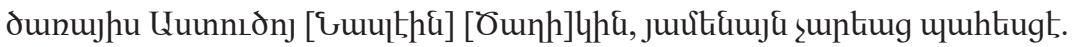
unțk:

27. Prayer for childbirth ... and give a child to the servant of God Całik (written on paper glued over the name of the first owner, 19th century, shłagir) ...

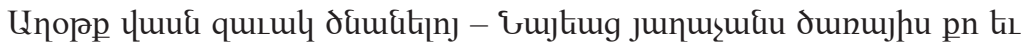

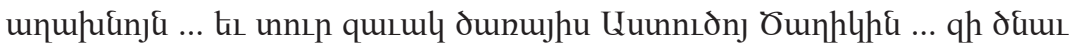
ưưnıli氏 ju2hump:

XXIII. Solomon chides the lord of demons

28. Prayer against the spells of the devils and als ... from the servant of God Całik (written on paper glued over the name of the first owner, 19th century, shłagir) ...

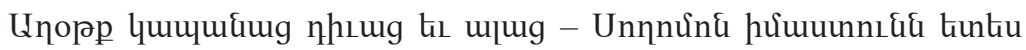

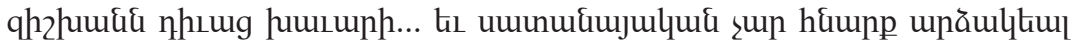

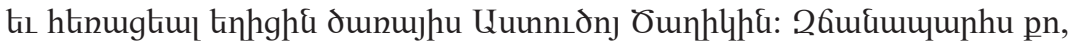
Strn, gnjg hưă tiı qzuıłnu pn nıunj hữ:

29. Prayer against the tpła and the al ... to the servant of God Całik (is written on paper glued over the name of the first owner, 19th century, shłagir) ...

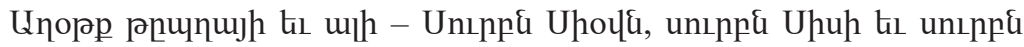

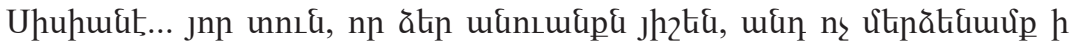

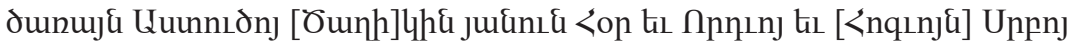

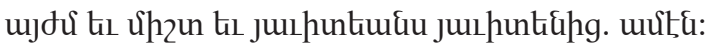

30. Prayer for successful sale and for everything ... the servant of God Całik (written on paper glued over the name of the first owner, 19th century, shłagir) ... to the servant of God Naslē (bolorgir) ... of the servant of God Naslē (bolorgir). Amen.

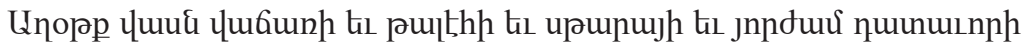

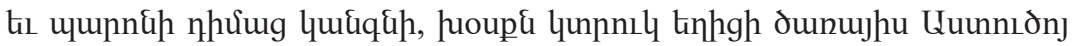

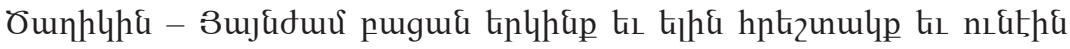

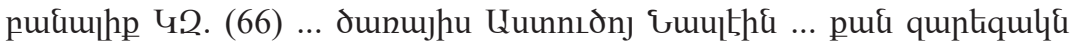

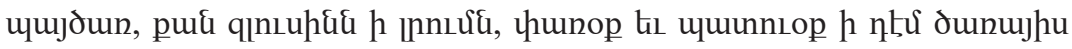
Luunnıonj Guulthu. ư⿰纟: 


\section{COLOPHON OF THE PRINTING HOUSE}

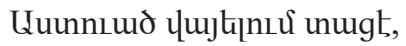

Uju htưujhцu, np qnumo t,

<ujnp tis tinpujnp, np uwj ungt,

fumnunnıptiuxp lujtiltugt,

ก々 sun hıрб umunuhtiugt,

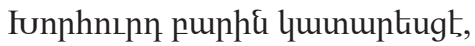

h hunpha dtipnıphı\&u huugt,

<ujp ưtinujhs qununnu unphi jh2tiugt,

Gl Jtin uuntiugu, np fum tigt,

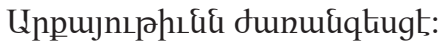

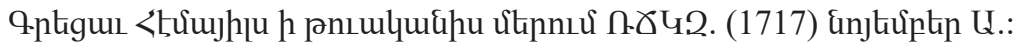

May God grant enjoyment,

This Amulet, that is written,

Fathers and brothers who take this,

May they enjoy it with peace,

May evil be far from them,

May the good come true,

May they live until old age.

Remember the printer of this in your prayers,

And afterwards, at Doomsday

May he inherit the Holy Kingdom.

The Amulet was written in 1166 of the Armenian era (=1717), on November 1 .

Note: The later printer saved even the date of the first publishing.

ANNOTATION: At the end of verso, on glued paper: rectangular, printed

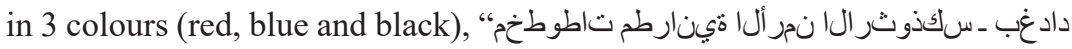

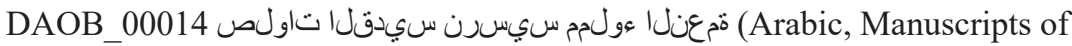
the Armenian Orthodox Diocese of Baghdad / DAOB_00014 / The prayers of Saint Nerses Shnorhali)26 Centre Numérique des Manuscrits Orientaux Dominicains - Mossoul - Fondé en 1990". 


\section{CONCLUSION}

The collection of Armenian Orthodox Diocese in Baghdad holds three Armenian Amulets in scroll format. The oldest one was printed in 1716 at the printing house of Grigor Marzvaneci in Constantinople (DAOB, Pr. n. 15). The manuscript Amulet was written 1736 in Erzrum (DAOB, Ms. n. 13), as the colophon reveals. The date of the third Amulet (DAOB, Pr. n. 14) eludes us, despite its preserved colophon. Careful study allows us to state that the publishers of DAOB Pr. n. 14 have used the Amulet of 1717 from the printing house of Astuacatur Kostandnupolseci as a prototype. Ten Amulets in scroll $(1716,1717,1718,1724,1725,1726,1727,1728,1729$ and one without date) are known from this printing house (Ghazaryan 2018a: 72). In the second copied Amulet (second half of the 19th century), the publishers used the same prayers and kept the colophon, but decorated it with new engravings. There are a few more unanswered questions regarding this Amulet, such as what was the printing house where it was created and what was the reason for keeping the date of the Amulet it was copied from. We hope that further research will help us to answer these questions.

The system of artistic decoration of the handwritten Amulet relates to the content of the texts of the invocations. They also represent the images of authors or personages, to which the texts of amulet-scrolls are dedicated. This is mostly typical for Armenian illuminated amulets, as well as for the early printed Armenian amulets. The image of the saint and the demon - al has interesting iconographic details that we were able to explain using written sources, ethnographic material and folk tradition. Such imagery in the Amulet testifies to the formation, development, and long-living tradition of Armenian folk beliefs.

\section{ACKNOWLEDGEMENTS}

As a Visiting Scholar at the Hill Museum and Manuscript Library (HMML, March-April, 2017, Collegeville, Minnesota, USA), Lusine Sargsyan had the chance to study the digitized collection of Armenian Amulets in DAOB (by virtue of a grant provided as part of the project of "Swenson Family Fellowship in Eastern Christian Manuscript Studies"). 
The authors of this article would like to thank Emanuela Timotin and the anonymous reviewers for Incantatio for their help in bringing this article into its final form.

\section{NOTES}

${ }^{1}$ The word "Amulet" with a capital letter is used here with the meaning 'handwritten or printed amulet' as a variation of manuscripts or books.

${ }^{2}$ For a brief physical description and full scanned copies of the amulets, see the following permanent links:

DAOB 13 - https://www.vhmml.org/readingRoom/view/136277 (consulted 15.04.2021),

DAOB 14 - https://www.vhmml.org/readingRoom/view/136278 (consulted 15.04.2021),

DAOB 15 - https://www.vhmml.org/readingRoom/view/136279 (consulted 15.04.2021).

${ }^{3}$ Usually, in the decoration of the Amulets we see the first steps of artists, sometimes scribes, who created their first miniatures. Previous researches (Ghazaryan 2013a: $43-4,84-5,106,109)$ showed that some amulets were decorated by scribes who were not miniaturists.

${ }^{4}$ One can find the name "Niatagir" only in the scroll Amulet kept in the collection of Matenadaran (N 544, 1716, Owner: Hakob, son of Petros Kałzvaneci).

${ }^{5}$ The author describes two manuscript Gospels.

${ }^{6}$ The author describes seven manuscripts.

${ }^{7}$ In Armenian illustrated amulets, Saint Sargis is often depicted on horseback with his son Martiros.

${ }^{8}$ The same is true of the female cannibal creature in Russian tradition; see Tadevosyan, Kotsinyan 2017: 339.

${ }^{9}$ According to Feydit, the reason was the threefold specialty (puerperal fever, abortion and infant mortality) of als that differentiated them from other demons (Feydit 1973: 228).

${ }^{10}$ The Armenian epic Daredevils of Sasoun, oral in its origin, was first published in 1874 in Constantinople by Garegin Sruanjteanc; later on many new editions of this epic were published. We are grateful to Tork Dalalyan (Institute of Archeology and Ethnography, National Academy of Sciences, Republic of Armenia) who directed our attention to this epic.

${ }^{11}$ David of Sassoun 1964: 49, First Cycle "Sanasar and Baghdasar", Part I, Chapter 16, lines 4-9 (translated by Shalian Artin). 
${ }^{12}$ David of Sassoun 1964: 24, First Cycle "Sanasar and Baghdasar", Part I, Chapter 8, lines 106 and 111 (translated by Shalian Artin).

${ }^{13}$ See http://www.ankyunacar.com/bible/.

${ }^{14}$ Daredevils of Sassoun 1964: 39, First Cycle "Sanasar and Balthasar", Part I, prose translation from Armenian.

${ }^{15}$ For more details about the content of early printed Armenian Amulets, see Ghazaryan 2018a: 70 .

${ }^{16}$ Originally there were more than twenty gravures.

${ }^{17}$ On the engravings of Grigor Marzvaneci, see also Ghazaryan 2018a: 71.

${ }^{18}$ For more details, see Ghazaryan 2018a: 73.

${ }^{19}$ Originally it was supposed to contain nineteen prayers.

${ }^{20}$ Prior to this study, two Amulets were thought to have been printed in 1717, but, as we will see, one of them was printed in the 19th century.

${ }^{21} \mathrm{http}$ ://www.letyrosemiophile.com/images/Imprimeurs/Laurent-et-Deberny-75.htm. We are grateful to our colleague Arpine Simonyan $(\mathrm{PhD}$ in Arts, Senior Researcher in Matenadaran) for help in identifying the engravings.

${ }^{22}$ In the brackets, the size (length) of each piece of the Amulet is given sequentially.

${ }^{23}$ Armenian scripts are divided into four main groups: erkatagir (from 4th century), bolorgir (from 10-11th centuries), notrgir (from 15th century) and shłagir (from 18th century).

${ }^{24}$ Read and translated by Knarik Sahakyan, Senior Researcher in Matenadaran.

${ }^{25}$ Read and translated by Knarik Sahakyan, Senior Researcher in Matenadaran.

${ }^{26}$ Read and translated by Knarik Sahakyan, Senior Researcher in Matenadaran.

\section{REFERENCES}

Ališan, Łewond 1895. Hin hawatk kam hetanosakan krōnḱ hayoć [Ancient Faith or Pagan Armenian Religion]. Venice: Saint Lazar.

Alpōyačean, Aršak 2003. Iraki hayerə [The Armenians of Iraq]. Vardan Gregorean

(ed.) Yerevan: "Matenadaran", Mesrop Mashtots Research Institute of Ancient Manuscripts.

Ačaŕyan, Hrač́ya 1977. Hayeren armatakan baŕaran [Armenian Etymological Dictionary]. Vol 3. Yerevan: Yerevan State University Press. 
Awgerean, Mkrtič 1810. Liakatar varḱ ew vkayabanutiwn srboć, orḱkan i hin Tōnaćuci ew ekelećwoy Hayastaneayć [Complete Life and Testimony of Saints in the Ancient Armenian Church]. Venice: Mxitarean Press.

Badalanova Geller, Florentina 2015. Between Demonology and Hagiology. The Slavonic Rendering of the Semitic Magical Historiola of the Child-Stealing Witch, in J. Cale Johnson (ed.), In the Wake of the Compendia: Infrastructural Contexts and the Licensing of Empiricism in Ancient and Medieval Mesopotamia. Boston/ Berlin: De Gruyter, pp. 177-205.

Cucak Mayr Atoŕ Surb Eĵmiacni nor staćvac jeŕagreri. Etchmiadzin. Official monthly review of Holy Etchmiadzin, 1952/April, 1961/December, 1962/August, 1963/ May, 1970/December, 1971/May, 1971/November, 1975/November.

Daredevils of Sassoun 1964. The Armenian National Epic by Leon Surmelian. Denver: Alan Swallow.

David of Sassoun 1964. Original text translated by Shalian Artin. Athens, Ohio: Ohio University Press.

Endoltseva, Ekaterina and Andrey Vinogradov, 2016. Beard Pulling in Medieval Christian Art: Various Interpretations of a Scene, in Anastasis. Research in Medieval Culture and Art, vol III , no. 1, Iaşi, ARTES, pp. 88-98.

Feydit, Frédéric 1973. Al et Thebgha. Revue Bazmavep, 2: 227-46.

Feydit, Frédéric 1986. Amulettes de l'Arménie chrétienne. Venice: Mxitarean Press.

Ghazaryan, Davit 2012. XV dari žapavenajev hmayilnerə [The Scroll-Shaped Amulets of the 15th Century], in Collection of Reports of the 6th scientific conference of young art historians (November 26-27, 2011). National Academy of Sciences of the Republic of Armenia, Art Institute, Yerevan: GITUTYUN.

Ghazaryan, Davit 2013a. Pahpanutyan greri ("Hmayilneri”) getarvestakan hardaranko (15-rd daric minč̀v 1659 tvakan) [Artistic Decoration of Scroll-Shaped Amulets (from the 15th Century until 1659)]. PhD thesis, National Academy of Sciences of the Republic of Armenia.

Ghazaryan, Davit 2013b. Žapavenajev hmayilneri tpagir aŕânnekə [The First Armenian Printed Scroll-Shaped Amulet]. Etchmiadzin, 8: 142-147.

Ghazaryan, Davit 2014. Kiprianos hayrapetə ew Hustianē kuysə XV-XVI dareri japavenajev hmayilneri gełarvestakan hardarankum [Bishop Cyprian and the Virgin Justina in the Artistic Decoration of Scroll-Shaped Amulets of 15th-16th Centuries]. Bulletin of Matenadaran, 20: 243-64.

Ghazaryan, Davit 2018a. Old-printed Armenian Amulets in Scroll of the Library of the Dudean Cultural House at Armenian Apostolic Patriarchate of Romania in Bucharest. Revue des Études Sud-Est Européennes, 56: 69-99.

Ghazaryan, Davit 2018b. Old Armenian Printed Talismans, in Memory of Printing and Publishing in the Middle East, Foreword by Dr. Mostafa El Feki, Intro- 
duction and ed. by Dr. Ahmed Mansour, Refereed Research Papers of the Fourth International Seminar on the History of Printing and Publishing in the Languages and Countries of the Middle East, Alexandrina, 27-29 September 2011, Egypt, Alexandria, Egypt: Bibliotheca Alexandrina, Writing and Scripts Center, pp. 73-85.

Ghazaryan, Davit 2019. Nor Jułayi Surb Amenaprkič́ vanki žapavenajev hmayilneri havaqacun [The Collection of Amulets in Scroll of the Holy Saviour Cathedral of New Julfa], in Levon Xač́ikyan (ed.), Collection of Reports. Proceedings of the International Armenological conference dedicated to the 100th Anniversary of academician Levon Xačikyan (28-30 June, 2018). Yerevan: Matenadaran, Nairi, pp. 460-467.

Ghazaryan, Davit and Lusine Sargsyan 2016. Some Armenian Amulets in Scroll from the Romanian Collections (part I). Revue des Études Sud-Est Européennes, 54: $13-42$.

Harutyunyan, Sargis 2006. Hay hmayakan ew žołovrdakan ałotḱner [Armenian Charms and Folk Prayers]. Yerevan: Yerevan State University Press.

Jacoby, Zehava 1987. The Beard Pullers in Romanesque Art: An Islamic Motif and its Evolution in the West. Arte Medievale. Periodico internazionale di critica dell'arte medievale, ser. 2, vol. 1, pp. 65-85.

Kiwrtean, Harutiwn 1932. Haykakan hnutiwnk y Ējmiacin, i Tawriz, i Bałtat. Sion. An Armenian Monthly of Religion, n. 11, Jerusalem: Saint James Press, pp. 346-349.

Lyavdanski Andrey and Andrey Toporkov 2017. Vvedenie [Introduction], in Andrey Toporkov (ed.), Sisinieva legenda v folklornikh rukopisnikh traditsiyax Blijnego Vostoka, Balkan i Vostochnoy Evropi [The Sisinius Legend in the Folklore and Handwritten Traditions of the Near East, Balkans and Eastern Europe]. Moscow: Indrik, pp. 13-28.

Macler, Frédéric 1928. L'enluminure arménienne profane. Paris: Libraire Orientaliste Paul Geuthner.

Malxaseanc, Stepan 1944. Hayerēn baćatrakan bararan [Armenian Explanatory Dictionary]. Vols 2-3. Yerevan: Armenian SSR Press.

Mazilu Marius and Emanuela Timotin 2017. Legenda o svyatom Sisinii v ruminskoi traditsiy [The Legend of St Sisinius in the Romanian Tradition], in Andrey Toporkov (ed.), Sisinieva legenda v folklornikh rukopisnikh traditsiyax Blijnego Vostoka, Balkan i Vostochnoy Evropi [The Sisinnius Legend in the Folklore and Handwritten Traditions of Near East, Balkans and Eastern Europe]. Moscow: Indrik, pp. 507-552.

Mescherskaya, Elena 1981. Siriyskie zaklenatelniye sborniki iz Matenadarana [Syrian Spell Books from Matenadaran]. Palestinskiy sbornik, 27: 93-104. 
Minasean, Lewon 1983-84. Nor Jułayi Surb Amenaṕrkič vanki hayerēn grčagir u tpagir hmayilnerz [Armenian Handwritten and Printed Amulets in the Scroll of the Holy Saviour Cathedral of New Julfa], Separate publishing of the "Hask" Armenological Review, New series, 4-5: 109-120.

Nersessian, Nerses (Vrej) 2012. A Catalogue of the Armenian Manuscripts in the British Library Acquired since the Year 1913 and of Collections in other Libraries in the United Kingdom. 2 vols. London: British Library.

Samuēlean, Serovbē 1905. Pasrayi S. Astaucacin ekełecioy jeŕagirnerə [Manuscripts of the Saint Astuacacin Church in Pasra]. Loys. Religious, literary, philological, political weekly, 26 [Constantinople, repr. in Antelias: Armenian Catholicosate of Cilicia 1987], pp. 636-639.

Sargsyan Aram and Petrosyan, Amalya 2003. Irak, in Hovhannes Ayvazyan (ed.), Armenian Diaspora Encyclopaedia.Yerevan: Haykakanhanragitaran, pp. 268-273.

Sargsyan, Lusine 2018. The Scene of the Last Judgement in the Art of Armenian Miniaturist Avag (14th century). Review of Armenian Studies, 2 (17): 139-158.

Sekulean, Ogostinos 1983. Ćucak hayerēn jeŕagrac Mxitarean Matenadaranin i Vienna [Catalogue of Armenian Manuscripts in the Mekhitarean Library in Vienna]. Vol. III. Vienna: Mxitarean Press.

Sukiasyan, Ašot 2009. Hayoć Lezvi homanišneri baćatrakan baŕaran [Explanatory Dictionary of Synonyms of the Armenian Language]. 2nd edition. Yerevan: Yerevan State University Press.

Tadevosyan Tadevos and Kotsinyan Shushanna 2017. Armyanskie amuleti i zagovori protiv ala i tpxi i Sisinieva legenda [Armenian Amulets and Charms against the Al and Tpgha and the Legend of Sisinnius], in Andrey Toporkov (ed.), Sisinieva legenda v folklornikh rukopisnikh traditsiyax Blijnego Vostoka, Balkan $i$ Vostochnoy Evropi [The Sisinnius Legend in the Folklore and Handwritten Traditions of the Near East, Balkans and Eastern Europe]. Moscow: Indrik, pp. 327-372.

Tēr-Vardanean, Geworg 2013. Ćucak Yarutiwn K'iwrtean havak'acoyi hayerēn žapawinajew jeŕagir hmayilneri [Catalogue of Armenian Handwritten Amulets in Scroll from the Collection of Harutiwn Kiwrtean]. Etchmiadzin, 3: 62-98.

Voskean, Hamazasp 1963. Cućak hayerēn jeŕagrać Mxitarean Matenadaranin i Vienna [Catalogue of Armenian Manuscripts from the Mekhitarean Library in Vienna]. Vol II. Vienna: Mxitarean Press.

Wildridge, Tindall 1899. The Grotesque in Church Art. London: William Andrews \& Co. 


\section{INTERNET LINKS}

http:/www.letyrosemiophile.com/images/Imprimeurs/Laurent-et-Deberny-75.htm https://www.vhmml.org/readingRoom/view/136277 https://www.vhmml.org/readingRoom/view/136278 https://www.vhmml.org/readingRoom/view/136279

\section{TABLE OF TRANSLITERATIONS FROM ARMENIAN}

\begin{tabular}{|c|c|c|c|}
\hline $\mathrm{U} u-\mathrm{A} a$ & $\mathrm{~h} h-\mathrm{I} i$ & $3 \mathrm{~J}-\mathrm{Yy}$ & $\mathrm{S}$ un $-\mathrm{T} \mathrm{t}$ \\
\hline $\mathrm{A} p-\mathrm{B} b$ & $\mathrm{~L}_{\mathrm{l}}-\mathrm{L} 1$ & $\mathrm{U} \mathrm{I}-\mathrm{Nn}$ & $\rho \mathrm{p}-\mathrm{Rr}$ \\
\hline$q q-G g$ & Ku hu $-\mathrm{X}$ x & $G_{2}-\breve{S} \breve{s}$ & $8 \mathrm{~g}-\dot{\mathrm{C}} \dot{\mathrm{c}}$ \\
\hline २ $\eta-D d$ & $\delta \partial-C c$ & $\mathrm{n} n-\mathrm{O} o$ & $\mathrm{~h}_{\mathrm{l}}-\mathrm{W} \mathrm{w}$ \\
\hline $\mathrm{E} t-\mathrm{E} e$ & $\mathrm{G} \mathrm{l}-\mathrm{K} \mathrm{k}$ & $Q_{乙}-\dot{\check{C}} \dot{\check{c}}$ & $\Phi \mathrm{h}-\mathrm{P}_{\mathrm{p}}$ \\
\hline $2 q-Z z$ & $<\mathrm{h}-\mathrm{Hh}$ & $\tau u_{p}-P p$ & $\rho p-\dot{K} \dot{k}$ \\
\hline $\mathrm{E} \mathrm{t}-\overline{\mathrm{E}} \overline{\mathrm{e}}$ & $2 \grave{a}-J j$ & $\Omega \Omega-\hat{J} \hat{\jmath}$ & $\mathrm{O} o-\overline{\mathrm{O}} \overline{\mathrm{o}}$ \\
\hline ᄃ $\mathrm{n}-\partial$ ə & ح. $\eta-€ ł$ & ก- $\mathrm{n}-\hat{\mathrm{R}}_{\mathrm{r}}$ & $\Phi \Phi-F f$ \\
\hline$\partial \partial-\dot{T} \dot{t}$ & $\gamma 6-\check{C} \check{c}$ & $\mathrm{U} u-\mathrm{S} \mathrm{s}$ & $\Omega_{l} n\llcorner-U u$ \\
\hline$\sigma d-\check{Z} \check{z}$ & $\mathrm{U} \mathfrak{u}-\mathrm{M} \mathrm{m}$ & บ. $u-V v$ & + li-ew \\
\hline
\end{tabular}

\section{BIOS}

Lusine Sargsyan is a Researcher at the Matenadaran Research Institute of Ancient Manuscripts, and a Visiting Lecturer at Yerevan State University. She has received grants from the Foundation of Sirarpie Der-Nersessian, Paris (2012 and 2015), and the New Europe Foundation, New Europe College Institute for Advanced Study, Bucharest (2013-14 and 2017). She was a Visiting Scholar at Hill Museum and Manuscript Library, Collegeville, Minnesota (in 2017). Her research interests include Medieval Armenian art, the art of Armenian Diaspora, codicology and paleography.

Davit Ghazaryan ( $\mathrm{PhD}$ in Arts) is a Senior Researcher, Curator of the Manuscript Depository of the Matenadaran Research Institute of Ancient Manuscripts, and a Lecturer at the Department of Armenian Art History and Theory at Yerevan State University. He received the grant of the Foundation Sirarpie Der-Nersessian, Paris (in 2016 and in 2017). His research interests 
Armenian Amulets from the Collection of Armenian Orthedox Diocese in Baghdad include Armenian manuscript studies and Printings, Armenian Art of Medieval and Modern times.

Image 1

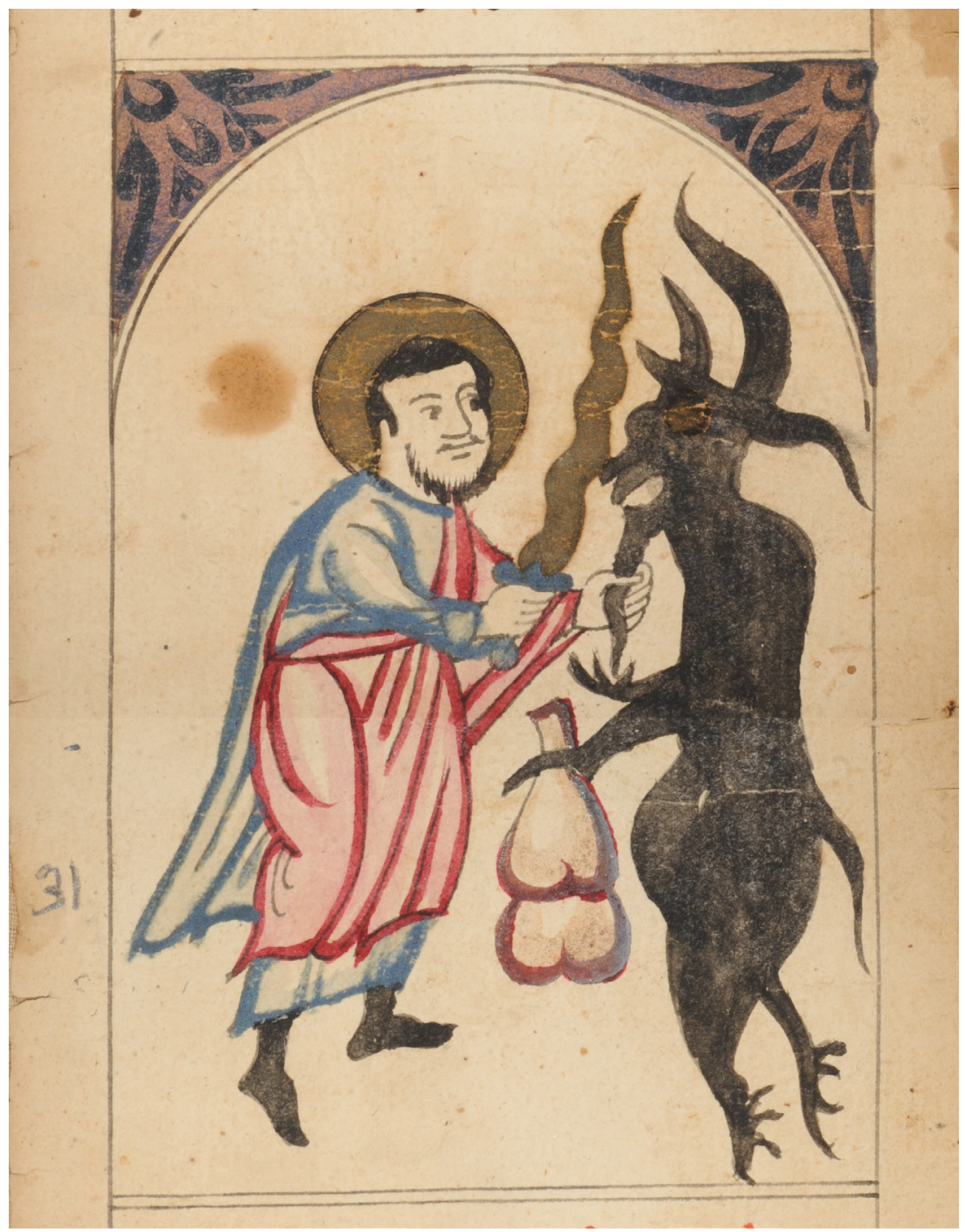

Saint Peter chides the demon - Al.

Iraq, Baghdad, Armenian Orthodox Diocese in Baghdad, MS 13 [HMML Pr. No. DAOB 00013]. Photo courtesy of the Hill Museum \& Manuscript Library, Saint John's University, Minnesota, USA, the Armenian Orthodox Diocese in Baghdad, and the Centre Numérique des Manuscrits Orientaux (CNMO), Erbil, Iraq. Published with permission of the owners. All rights reserved. 


\section{Lusine Sargyan, Davit Ghazaryan}

Image 2

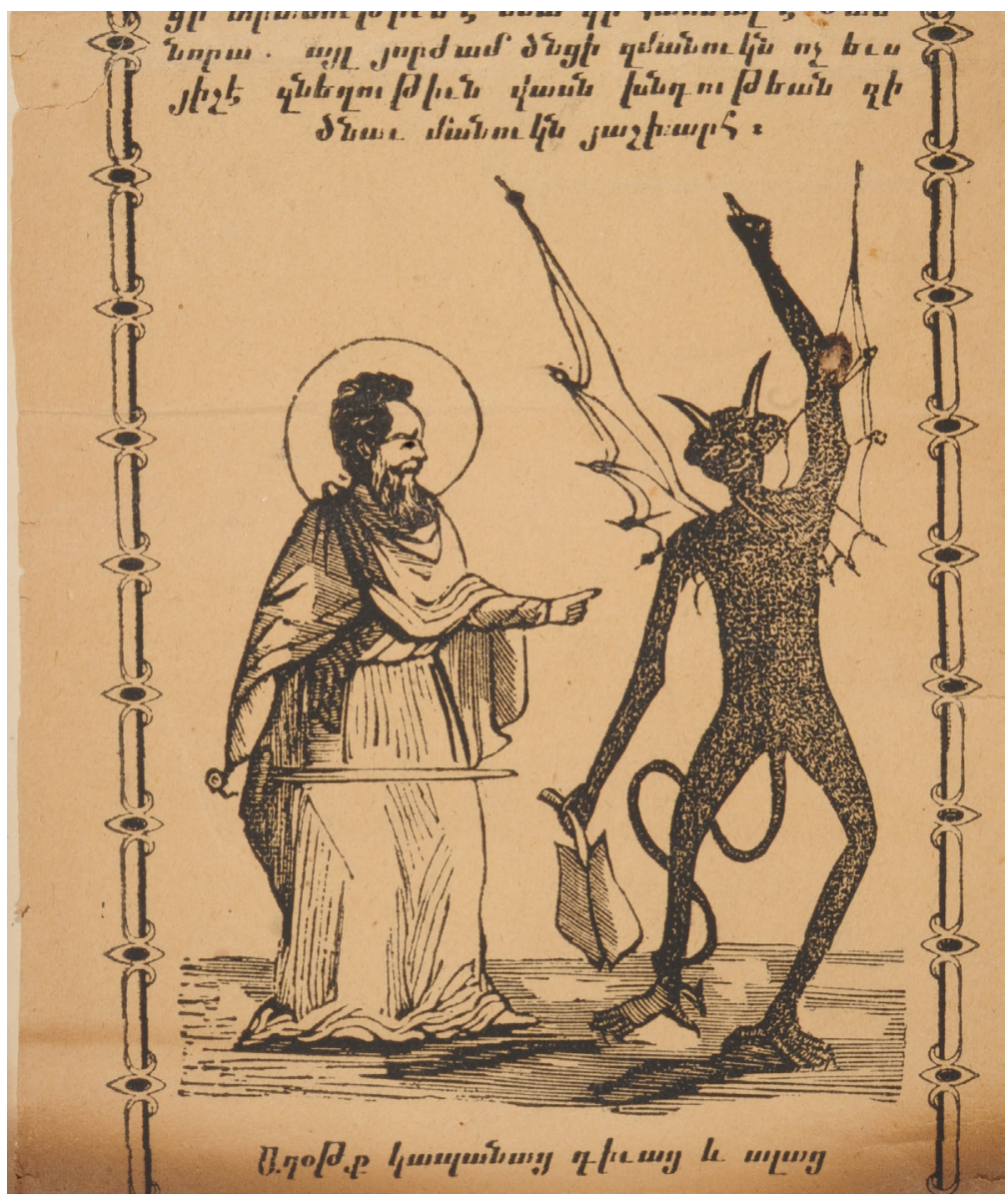

Solomon chides the lord of demons.

Iraq, Baghdad, Armenian Orthodox Diocese in Baghdad, MS 14 [HMML Pr. No. DAOB 00014]. Photos courtesy of the Hill Museum \& Manuscript Library, Saint John's University, Minnesota, USA, the Armenian Orthodox Diocese in Baghdad, and the Centre Numérique des Manuscrits Orientaux (CNMO), Erbil, Iraq. Published with permission of the owners. All rights reserved. 
Armenian Amulets from the Collection of Armenian Orthedox Diocese in Baghdad

Image 3

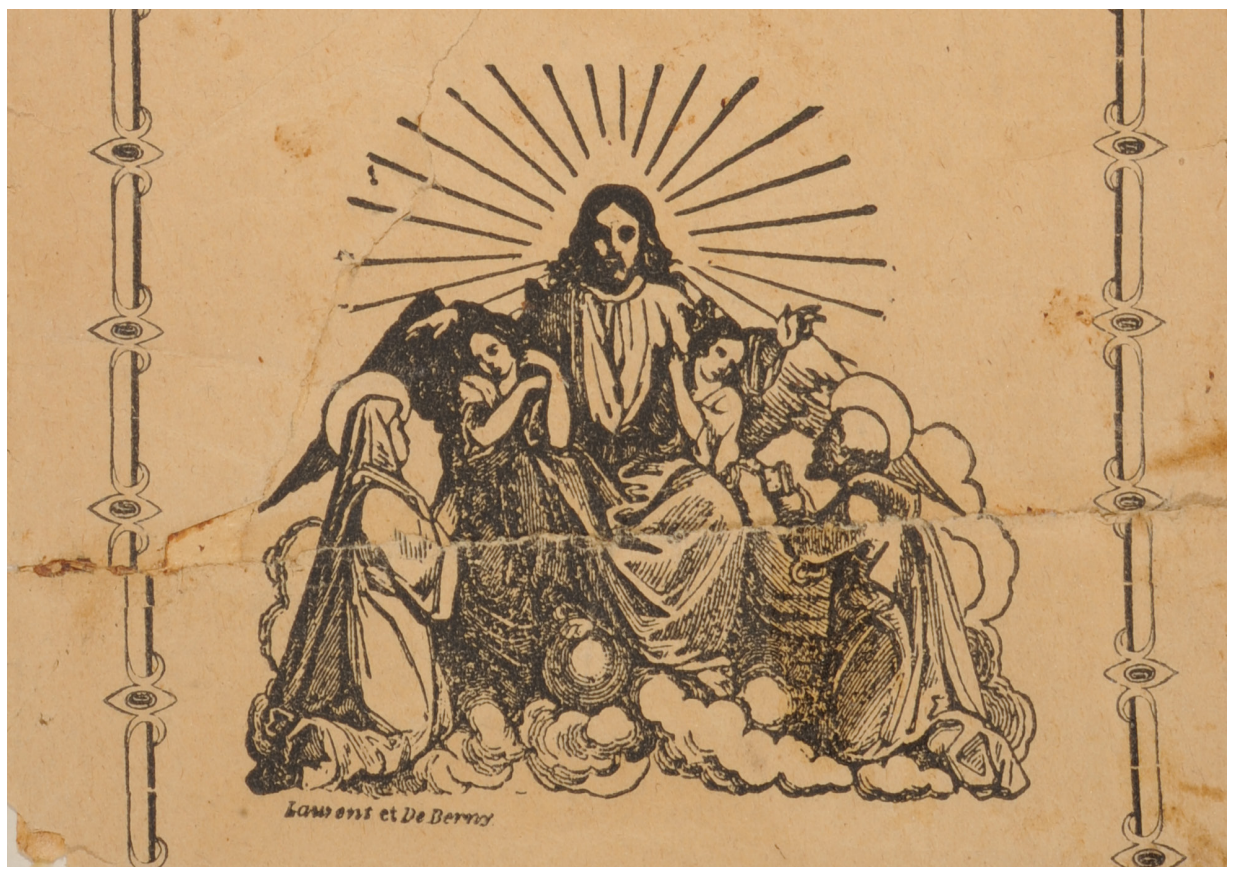

The Intercession

Iraq, Baghdad, Armenian Orthodox Diocese in Baghdad, MS 14 [HMML Pr. No. DAOB 00014]. Photos courtesy of the Hill Museum \& Manuscript Library, Saint John's University, Minnesota, USA, the Armenian Orthodox Diocese in Baghdad, and the Centre Numérique des Manuscrits Orientaux (CNMO), Erbil, Iraq. Published with permission of the owners. All rights reserved. 